\title{
Ruptures, Resilient Empires, and Small Divergences
}

The warfare and global tension to which the Luso-Hispanic complex found itself exposed undoubtedly posed the greatest challenge faced by the accords on which it had been based since the sixteenth century. This challenge would appear particularly in the system for mobilizing resources and in taxation in the different territories, which comprised an integral part of that system. It would, moreover, emerge most clearly in the extent to which the composite states' most important principle, that which limited the transfer of resources among their parts, continued to be violated.

The ensuing political ruptures, with many parallels elsewhere in Europe, would take the form of conflicts between the periphery-and the empire's different parts - and the logic of the government at the empire's dynastic centre. The result would be important for the history of these diverse territories, as well as for their political economies.

\section{Olivares’ Challenge to the Imperial Elites}

One of the most important reactions to the stress imposed upon the imperial system undoubtedly entailed the reformism and increase in fiscal pressure from Madrid. Although a well-known development, its fundamental landmarks merit consideration in relationship with this book's argument and, in particular, from the perspective of the relations between the Crown and the elites in the framework of the balance between accord and conflict consolidated during the sixteenth century (Chap. 4).

(C) The Author(s) 2019

B. Yun-Casalilla, Iberian World Empires and the Globalization of Europe 1415-1668, Palgrave Studies in Comparative Global History, https://doi.org/10.1007/978-981-13-0833-8_8 


\section{Reformism}

The reforming spirit in Spain was most clearly embodied in the person of the Count Duke of Olivares (Rome, 1587-Toro, 1645). A member of the Guzmán family hailing from Andalusia and a lateral branch of the House of Medinasidonia, don Gaspar de Guzmán provides an exceptional portrait of the sort of noble who, without being the head of a major lineage, found-and took-his chance to advance in the fluid situation created by the circulation of elites (Chap. 4). In an episode that was typical of the internal tensions within these lineages, his family had found itself confronting the head of the lineage, the duke of Medinasidonia, over the claims of his grandfather, don Pedro de Guzmán, to the duchy (Chaps. 1 and 4). Thanks to his services in Seville and abroad, don Pedro had enjoyed the favour of Charles V. Like so many other families, this one carried the stigma of conversos in its past. Don Gaspar's father, don Enrique de Guzmán, made use of his notable political capital to marry a daughter of the Count of Monterrey, bringing him a dowry of 60,000 ducats and ties to one of the kingdom's most prominent families. His bride, doña María Pimentel de Fonseca, enjoyed the inestimable immaterial capital of having been miraculously made healthy by Teresa de Ávila, or so at least it was said. Don Enrique, Count of Olivares, served as ambassador in Rome and as viceroy in Palermo. His career meant that his income, drawn from important estates in Andalusia, was supplemented by extraordinary emoluments and also strengthened his political and personal capital by adding transnational qualities and ties. Thus the future Count Duke, despite being the youngest of three brothers, was baptized by the Cardinal Aldobrandini, the future Pope Clement VIII. Upon returning to Spain, don Gaspar was able to fritter away a large part of his fortune in a spending blitz at court that at least secured him a good marriage. This gesture was typical of the 'double economy' of the nobles' patrimonial management (see Chap. 5). 'The prodigality of his gestures', says Elliott, 'would strengthen his claims to the status of grandee of Castile'. The squandering of money was obviously a form of investment. After a few years in Seville, don Gaspar returned to Madrid and navigated the conflicts between court factions with considerable skill, eventually binding himself to the Zúñiga faction, the family of his wife, and thus securing access to the new king, Philip IV, on the death of his father (Philip III) in 1621. The future Count Duke had a solid humanistic training, in part acquired in Italy, and was well acquainted with the world of Spanish universities, having been sent to 
study at Salamanca precisely because of his status as third-born son. While a student at Salamanca, he had in fact served as the university rector (Elliott 1990, chapter 1).

His years in Seville gave Olivares a good understanding of the urban world and the internal conflicts and agreements between the oligarchies; Seville also taught him to understand the monarchy's global dimensions. Olivares' time in Madrid coincided with the outcry for reform. His solutions to the problems are well known and above all were set out in the scheme for the so-called Union of Arms, a sort of army agreement to be imposed upon the different kingdoms, and the establishment of local public banks (erarios) (Elliott 1982; Dubet 2003). The two schemes went hand in hand. The erarios were conceived as a means of financing the king and even of making credit circulate through society, as well as a way of sustaining a series of army units in the peninsula. But, also-this was the purpose of the Union of Arms-Olivares sought to engineer the creation of permanent army units in all kingdoms and provinces, including America, with the firm proviso that they would provide each other with mutual assistance. He also fully believed that a new merchant spirit should be encouraged among the aristocracy (without doubt this idea was a legacy of his life in Seville) - that the Crown should make better use of the nonCastilian nobilities and that trading companies, similar to those of Holland and England, should be established (Elliott and de la Peña 2013).

The modernity or character of this programme cannot be assessed here; what concerns us is the way that it affected the pillars upon which the dominant coalition had been built and its ulterior effects on the country's political economy.

Despite his maxim of multa regna sed una lex, Olivares was not a 'statist' in the modern sense, nor had he overcome the patrimonial concept of the monarchy. The Union of Arms implied, as has so often been stated, the ending of key aspects of the status quo, as it broke with the idea that the resources of each of the separate kingdoms should be employed only in its own defence. And, worse, this scheme would be implanted not only in Castile, where this precept had already been tacitly applied (even if the Castilians were loath to admit it), but across the empire. It also implied a strong displacement of the power of coercion and the administration of violence towards the monarchy, even when, as Olivares himself recognized, the local authorities were to be permitted to recruit troops. ${ }^{1}$ Even more

\footnotetext{
${ }^{1}$ According to Elliott, 'Olivares was highly disposed to promise that the recruitment and payment of these troops would be managed entirely by local officials' (1990, p. 255).
} 
destabilizing was the programme for the erarios, despite their being sometimes supported by the procuradores in the Cortes themselves. It at least made it very difficult to arrive at an agreement. This plan, which had been reformulated several times since its original version, fell short of a financial revolution of the sort that was cementing the success of the United Provinces (Chap. 4), given that Olivares' erarios operating with debt had nothing in common with a system of budget and debt bonds endorsed by the Cortes. Why, then, did the local elites resist them so bitterly? First, the deposits of these banks, far from being the outcome of the voluntary purchase of debt bonds (as was the case in Holland and, after 1694, England), were to originate in forced loans. On another level the plan also entailed an implicit attempt to remove decisive power from the urban oligarchies and the Genoese and to give it to the Crown. The oligarchies viewed the prospective eclipse of the Italian financiers with some relish but were rather less keen on the prospective loss of their capacity to control the king. Many patricians also resented the proposed reform of the tax system on the grounds that the abolition of the millones would entail their loss of power on the local level (Ruiz Martín 1990a). And these misgivings were often combined with others about the wisdom of Olivares' plan to substitute Genoese bankers for Portuguese financiers of Jewish converso origin, which added an element of religious prejudice into the equation. The Genoese at least benefited from the cultural capital afforded by their status as Catholics untainted by suspicion; this same concept or ideal provided a basis for the conflictive pact and, it could be said, the mortar that united this society.

If the Union of Arms also worried the nobility, then the arrogance of Olivares in seeking to overhaul its economic grounds was hardly the best balsam. The favourite probably allowed himself to be carried away by the image of a Seville aristocracy that tried to reconcile activities based upon commerce with its noble status (Pike 1978), of whom the most eyecatching example was, of course, the duke of Medinasidonia, up to his neck in illegal commerce in his estates in the lower Guadalquivir (Domínguez 1973). But trying to introduce merchants' habitus among the Spanish nobles went against not only their cultural beliefs but also against a form of moral economy that, if more complex than is sometimes believed, was at the heart of an economy of legitimation that fed the group's social capital. Despite the complaints of the Cortes that local banks were unfair because the nobility contributed little to them, the very existence of the erarios implied that a good part of the noble auxilium 
should not be understood in the context of the direct and personal servicefavour (do ut des) exchange with the king that was the basis of their social consolidation and even survival as a class and power. Moreover, the Cortes themselves complained that 'this contribution is not voluntary, but forced and the nobility has never paid a personal contribution of this sort' (quoted by Domínguez 1973, p. 23). Something similar could be said about Olivares' plan to see the nobles educated at the universities, which was also a way of moving processes for the formation of social and cultural capital away from the family and lineage into the public domain. If this sort of measure might have had particular appeal to the second-born sons of noble houses-Olivares himself cannot have been entirely unaware of this element of it, as a third-born son-it would have broken with the idea that the best education for a member of the first estate was to be trained in court intrigues and knowing who was who. Rather than receive an intellectual schooling - which was not entirely absent from the aristocracy, as the biography of Olivares himself shows - the most profitable activity for the titled nobility was to acquire social and relational capital in Madrid. If this were not enough, in Castile the idea of further integrating the peripheral nobilities in the functioning of government was seen as spitting in the faces of those who extended their lineages and families precisely through these political resources, which were crucial to their social promotion.

The reaction to these proposals was quite varied. At one extreme stood the direct opposition in the Cortes of Aragon and Valencia, although this soon gave way to acceptance; at the other extreme was their total rejection in Catalonia; at other points they gave rise to struggles over specific aspects or projects and their general context. Some of these struggles elicited brutal criticism and biting satire from most refined practitioners of the Castilian language (Egido 1973). An army of wordsmiths, Quevedo among them, was mobilized against these plans. All of them made use of channels of communication that, if based upon the incipient public sphere, were the product of patronage and clientele systems that meant these quill-wielding soldiers ultimately served the interests of noble factions.

\section{Fiscalism and Upheavals}

Plans for reform were to be frustrated not only by resistance to them but also by the urgent and overwhelming need for money created by war, which compelled the government to take the existing status quo to the very limits of its possibilities and prioritize day-to-day solutions rather than 
the long-term reforms. Indeed Olivares brought the balance of this system near to the very limits of an absolutist regime - that is to say, to tyranny.

Olivares' measures would enrage all sectors of the Castilian elites, beginning with the urban oligarchies. This is the basis of the traditional interpretation that underlines the conflict between Olivares and this social sector. Thus the Cortes of Castile were urged to concede more servicesmillones, above all (Artola 1982) — and even to impose a levy on flour and salt, both of which would have had a major impact on the groups with the lowest incomes, or to create new taxes, like the so-called cientos, and the media annata, and withhold the payment of juros. ${ }^{2}$ The impatience and determination that characterized Olivares led him to introduce measures that could only be justified by the assumption of absoluta potestas. This was emphatically the case in the manipulation of the vellón coins whose value was permanently reduced, despite many later efforts to reinstate their previous worth (Hamilton 1975, chapter 4). This course of action was first undertaken by Philip III. But the reign of Philip IV was marked by processes of currency devaluation and later revaluation that gave rise to a period of inflation and deflation whose effects were even worse than the simple minting of coins. Moreover, these acts were accompanied by the seizure of shipments from the Indies, forced loans, and so on. On top of all of these measures came frequent recourse to forced loans in the form of donativos that at times took the form of asientos. ${ }^{3}$

An additional problem lay in Olivares' treatment of the Cortes, over whose parsimonious processes and procedures he would trample, to the outrage of many. On top of this came the debate on the nature of the vote of the procuradores, which was alternatively understood to be decisive or consultative. The cities had previously sent their procuradores armed only with a consultative vote, that is to say a preliminary or advisory one, on the proviso that they would then return to the municipal councils for permis-

${ }^{2}$ (Domínguez 1983, pp. 295-309). The cientos consisted in a raising of the percentage of the theoretical rate of the alcabalas. The media annata was a tax on the inheritance of offices and other mercedes. Taxes were also created on the use of paper and so on.

${ }^{3}$ Domínguez Ortíz found 13 such donativos or general loans - that is to say ones that led to general campaigns for their collection across the kingdom-during the reign of Philip IV, with a noticeable intensification in the 1630s and, above all, from 1635, when war with France broke out (1983, chapter VII). In addition to these measures, there were individual or specific donativos, sometimes given to offset previous ones with individuals or corporations. These were grounded in the idea of auxilium, closely tied to the 'antidoral' theory present in the moral economy of the time (Clavero 1991). 
sion to vote definitively (voto decisivo). The heart of the matter lay, logically, in Olivares's shortcutting of this second phase by taking the first vote to be decisive, thus saving time and giving the procuradores, who were more manageable than the oligarchies of the town halls, greater freedom of action and corruption (Fortea 2008).

But the absolutist methods of Olivares also affected the nobles. It is not certain that the Count Duke really sought to apply measures trying to limit the grants aristocrats received from the Crown (Yun 2002a, chapters 6 and 7), but any hint of a policy of this sort could create problems among a group who considered themselves to be the rightful recipients of royal largesse. That he began by awarding offices in Castile to the members of other aristocracies (Elliott 1982) should be seen in this light too. The high nobility saw its interests prejudiced by the currency devaluations, which considerably reduced its incomes in coin and made them more difficult to collect at a time when they were growing much more slowly than prices and even beginning to fall in real terms (Jago 1982; Valencia 2010, vol. I, pp. 542 and ff). The measures to reduce the official rates of interest the Crown paid for the juros may have followed market tendencies but also hit the pockets of many nobles, for whom they constituted an important source of income (the same was of course true for urban elites). Worse, on several occasions Olivares established criteria with regard to the conferral of favours based upon service that in many cases did not take into account what the high aristocrats considered to be distributive justice (in their view, considerations of rank meant more that offices and grants should be made mainly to them (Cárceles 1994)). The effects of such a policy could not be positive among a group that felt all of its interests to be threatened-its economic incomes, its political opportunities at court, and its access to the king, which the valido sought to limit or mediate. And the same effect was produced among the high aristocrats and the elites in general by the retention of half of the yields from juros (Domínguez 1973).

The fiscal absolutism of Olivares even touched the Church. On top of the Three Graces (subsidio, excusado, and cruzada; see Chap. 1) came a number of other voluntary donations (donativos; see Chap. 4) and services. If the fiscal weight of these revenues was being reduced by inflation, it was frequently the case that they (and above all the cruzada) were not used for the cause for which they had originally been granted, a 'misuse' which created considerable indignation among the clergy. But the principal problem was the millones, a service from which churchmen considered themselves to be exempt. For obvious reasons, they saw their interests 
prejudiced by the tax on franked paper, papel sellado (Gelabert 2001, pp. 150 and ff. 168). Their sense of injustice was even greater in relation to the war with France, which could hardly be presented as a fight for the defence of Christendom.

In this context, it is not difficult to understand why some have spoken of 'the convulsions of Castile' (Gelabert 2001). An uprising took place to protest the imposition of the salt tax in the Basque Country, whose fisheries and salting industry were badly affected (Fernández Albaladejo 1975). A long series of reactions against the taxes and the manipulations of the vellón currency occurred, and even after the fall of Olivares, there were altercations in cities such as Lorca and Palencia and in the Rioja region (Domínguez 1973, p. 20). Tensions would lead to risings between 1647 and 1652 in Andalusia, where even Córdoba and Seville were affected, when the poor harvests aggravated an already difficult situation and the local patricians were unable to control the people and in one case even incited them (Gelabert 2001; Domínguez 1973). Highly significant was the presence among these rebels of members of the local elites and clergymen; sometimes indeed it was they who led risings or encouraged them through their incendiary sermons.

If the cities broke with the valido, the nobles soon followed suit. They even went as far as a collective rebellion, a sort of a 'strike of the nobles', an inelegant but eloquent act - the abandonment of the political and constitutional functions of their class, specifically through their refusal to accompany the person of the king as a gesture of auxilium and consilium. The most serious noble protest was, however, the conspiracy led by two relatives of Olivares, the heavily indebted duke of Medinasidonia and the Marquis of Ayamonte, who took advantage of the rebellion led by João de Braganza in Portugal and, indeed, sought his help (Domínguez 1973; Salas 2013). In a certain way, this act provides yet another example of the tensions inherent in this sort of extended noble lineage frequent at court. But this episode had deeper roots and might even be profitably compared with events from as far back as the fifteenth century, when tensions of this sort were capable of combining with more general political processes to destabilize the entire political system. And this movement continued in 1648, being carried forward by the duke of Hijar in Aragon. Among the clergy things became so bad that a cesatio a divinis was sometimes proclaimed, meaning that they refused to administer religious rites. The bishops of Seville, Murcia, and Osma led acts of resistance or protest (Domínguez 1985, pp. 366-7). The wars of Mars were almost strangling 
the good works of Minerva; the grounds for complaint and rebellion were at times motivated by private interests but increasingly justified by the reigning political theory of the day.

\section{Castile: Change and Continuity}

\section{Reshaping the Conflictive Pact at the Core of the Empire}

The protests discussed above would lead to important changes, but rather than rupture the conflictive pact, what emerged was a re-composition of it.

Despite these tensions, the Cortes and urban elites were able to resist the demands made of them. Many of Olivares' measures eventually led to-or, indeed, were from their very inception designed to achieve-more centralized forms of financing. Other proposals maintained and even, in some cases, strengthened the power of elites and their capacity to renegotiate with the Crown, even if-and this was the crux of the matter-they provoked a series of changes with the apparent agreement of both sides.

The negotiation over the millones and the subsequent sisas continued, and this was not necessarily bad business for the oligarchies, as an eighteenth-century text, Ruiz de Celada's Estado de la Bolsa de Valladolid, showed (Yun 1990; Ruiz Martín 1994). Even if urban tax systems were beginning to experience insolvency, the chance to exercise the dual roles of lender and manager of the debt, as a member of the town council, offered the elites notable advantages. ${ }^{4}$ The sale of offices or the failure to abide by promises to absorb those already sold - a measure for which elites clamoured-meant that the oligarchies retained a social capacity to reproduce themselves. As in the previous century, the sale of noble titles continued to be seen as an opportunity and spigot for the ambitions of the oligarchies.

A very interesting part of this phenomenon lay in the donativos. This system was doubly useful for the elites in spite of their appearance of forced loans. In exchange for all manner of privileges, the king received a series of

\footnotetext{
${ }^{4}$ This mechanism has been set out in Chap. 4. It is worthwhile, however, to underline that the censos, unlike the juros, were not set on the debt of the treasury in general but on specific revenues. In this situation, whenever there were problems in claiming payment, they had to be resolved by the monarchy's administrators. For this reason a regidor, a member of the town council, always had a say on the order of payment, which was crucial in times of difficulties.
} 
'donations' in money. In some cases, these were practically forced payments and provoked resistance, but normally it was not difficult to arrive at an agreement of some sort whereby the king provided important compensations. Only in the 1629 donativo Seville provided a loan of 500,000 ducats ( $5 \%$ of the income of the royal tax system at this point). In compensation it received, among other things, the return to its jurisdiction of towns or villages that had been recently sold and diverse judicial benefits; another privilege, which curiously benefited the patricians rather than the city itself, meant that officials (specifically, the jurados and regidores) of the municipal authority could not be arrested for having failed to pay their taxes (Martínez Ruiz 1992, pp. 266-7). In Andalusia, where extensive municipal properties existed, the towns asked for the right to privatize common lands to the benefit of a city or, sometimes, an individual (De Bernardo 1994). All of this constituted an attack upon the inalienability of the royal patrimony, a precept which the cities had so jealously guarded in the fifteenth century (Chap. 1). Also involved in trade-offs of this sort were monopolies on trade or on fishing, hunting, and taverns. Equally the municipal councils obtained privileges over their own jurisdictions: improved or extended scope to regulate the local market or the right of appointment to municipal offices which were previously of a royal prerogative, such as alcaldias mayores or veedurias (overseer of the local market) (Andrés and Lanza 2008). Given that normally these donativos were paid for by sisas (excise taxes) set on the consumption of basic products and that many of these political and economic resources were habitually employed to benefit the oligarchy, it is easy to see what lay behind all of this. But subscribers to the donativos were not only cities and towns. Moreover, many donativos were subscribed to by private individuals. As one royal decree put it, donativos were about 'speaking to all' (Domínguez 1983, p. 203). Among their subscribers we find nobles, who managed to obtain permission for censos to improve or sell parts of their mayorazgo. Equally some guilds and individuals of all kinds figure in the records (Domínguez 1983, chapter VII). In the final analysis, the donativos pulverized the relations between king and kingdom by making these relationships much more atomized and individualized. This was a genuine revolution that broke with the corporate force of the Cortes, even if this institution sometimes managed to intervene in their administration (see below).

Highly significant to this new relationship of atomized corporatism was the aforementioned Consulate of Seville, which would prove positive and, 
more important, comfortable for both parties and perpetuated an American commercial policy that would be highly harmful to the application of any sort of mercantilist programme, as we have seen.

Another crucial point in this new arrangement between the Crown and the kingdom was the resolution of the dispute over the consultative vote against the decisive vote. The kingdom, embodied in the Commission of the Millones, enjoyed a period in which it appears to have held a strong hand in negotiating with the king. This occurred, however, in parallel to a situation whereby each city with a vote in the assembly maintained its right to reach its own private agreement with the Crown in regard to both the concession of taxes and (especially) their method of collection (Fortea 2008). The end of this story would be crucial. The cities themselves, conscious of their power and influence, came to prefer to put an end to the Cortes, whose importance had in any case been declining. Everything indicates that they now preferred not to reconvene as an assembly, many of them being keen to establish a direct relationship with the king. The king, of course, seems to have been of the same opinion (Thompson 1993). This development, one of the keys to the evolution of Castilian constitutionalism, can be explained by the shift from a concept of the procuradores as representatives of the kingdom to one that, in practical terms, had them as representatives of each city with votes in the Cortes (Fortea 2008). This, of course, was a very different trajectory to the one followed by countries such as England.

Be that as it may, the result of the pressures generated by the Count Duke, and the need to relax them in order to reconstitute relations between king and kingdom after his fall, resulted in a greater degree of absolutism (evident in measures that went against the laws of the kingdom, such as the monetary manipulations) but which, without parliamentary mediation, would reinforce a growing localism.

The high aristocracy found itself in a similar situation. Despite the efforts of the Count Duke, it was impossible to sever the service-favours relationship, as it was essential to the patronage system and, indeed, to the political culture. A study (Yun 2002a) demonstrates that this group continued to receive many favours, privileges, and offices; in fact, no reduction in their conferral can be discerned. If, perhaps, comparison should be made with the concessions made to families from outside the titled nobility-something which in fact does not appear to have been frequent for this type of favour - then it is clear that the conferral of monetary payments (ayudas de costa), offices, positions at court, noble titles for family 
members, and estates and habits in the Military Orders was not only frequent but remained at the same levels seen in the previous period. In these decades the diplomatic service became ever more dominated by the aristocracy, as did the viceroyalties. Even measures such as the reduction of interest rates on juros or the minting of more money were cushioned: as the lowering of interest rates also affected the censos taken out on their mayorazgos, the nobles were able to substitute existing debts for new censos taken out at lower interest rates. Transfers of this sort were nearly always done with the permission of the Crown, which had few reservations about allowing them. Again, this policy can be seen as another form of royal favour and a means of relegating the mutual relationships. In other countries the sale of noble titles has been seen as a symptom of an 'inflation of honours' that prejudiced the high nobility; yet in Spain it also meant that many second-born sons and other members of these families acquired titles. For this reason its effects in Castile-and, perhaps, elsewhere-were perhaps not negative for the high aristocracy, even if they must have left some imprint or mark on the internal changes of this social sector. Despite the effects on the high aristocracy of new methods for raising troops (see Thompson's views above), the need to maintain a military mobilization system that had yet to eliminate private armies raised by contractors in fact strengthened the role of great nobles and the seigniors with peasants on their estates. It has even been said that as a result of the recruitment drives by nobles, 'the señorio, both as a source of soldiers and honorific coronels, and as a power structure that held administrative sway over much of Castile, assumed new importance in an age when its economic resources had never been so ill-fitted to the needs of the Crown' (Mackay 1999, p. 130). Far from the image of slumbering seigniors and great nobles who were finding their capacity for enforcement steadily reduced, what happened in Castile was a much more selective process; this having been said, it absolutely did not amount to the loss of power by the seigniors. If some cases can be found to suggest the 'fall of the nobility', these are more convincingly explained by absenteeism, the distances involved in managing estates, and the related problems of control and monitoring that were so common and exploited by stewards (mayordomos) and local agents. Perhaps it is not possible to speak of a process of 'refeudalization', but the relationship of symbiosis and conflict between nobility and Crown was strengthening the theoretical power of the former (Yun 1994a). And this was achieved on the basis of the disappearance from 1538 of a corporate institutional relationship in the Cortes. That is to say that, in the same way 
that was happening in other sectors of society, an absolute king now negotiated and formed relationships not with a corporation but with each and every noble house.

Something similar could be said of ecclesiastical institutions. Their resistance to taxes was logical, and the mediation of two Popes, Urban VIII, decidedly pro-French, and then Innocent X, in proroguing the millones, previously conceded to Philip II, was especially corrosive (Domínguez 1985 , pp. 232-3). Yet the concession of some taxes was almost logical, as the Pope also received a part of them. But it has also to be taken into account that some contributions, like the cruzada, were not paid by the clergy but rather were the result of bulls sold to the faithful. Moreover the fraud was common in payments by the clergy, as became very clear in a well-known case from Valladolid (Gutiérrez 1989; Yun 1990). The Church was not deprived of the resources that originated in its special relationship with the Crown. Ecclesiastical entitled properties, so criticized by the arbitristas, increased in number, the very opposite of what was happening in many other countries of the time, France included (Chap. 6).

In this context it is relatively easy to understand developments in the king's justice and, specifically, the Chancelleries, as well as the fragmentation of the juridical system that we have mentioned before (Chap. 5). Very possibly this situation did not serve to increase juridical security or to reduce the transaction costs for many economic activities; on the other hand, it certainly reflected the many means and varied methods of enforcement of the law and the clashing of jurisdictions, a legacy of the sixteenth century that was growing in strength. This, inevitably, would have an impact upon the allocation of resources and economic performance. As a matter of fact, for some decades this do ut des paved the way for the managerial criteria less conducive to economic improvements (see Chap. 5).

\section{Patrimonial Management, the Economic Resilience of Elites, and Property Rights}

Very few of the changes for which the arbitristas had clamoured-and were still clamouring-had been introduced. The quantity of mayorazgos founded between 1600 and c. 1650 is not known. But we do know that the institution not only grew in strength but also became increasingly valued by local elites who saw in it both an economic strategy and a highly rational way of conserving and recycling their social and political capital 
(Hernández 1995). Many continued to invest massively in political resources and privileges, as can be seen in the rise in the price of the office of regidor in both Madrid and across Castile (Gelabert 1997, pp. 166-167). Putting money into the Military Orders - that is to say in social and political capital-remained at the same level and perhaps even grew, at least among urban elites (Hernández 1995, p. 226). The use of public properties, common lands, and propios lands (as we said those belonging to towns and villages) for private profit did not come to an end (De Bernardo 1994). As we have seen, such practices diminished the possibilities of agrarian innovations. As was by now commonplace, the traders of the Consulate of Seville continued to manage their businesses on the basis of their privileges, thus favouring both the arrival of non-Castilian products and the sky-high profits obtained by foreigners (Bernal 1993).

These practices, and above all those that allowed the acquisition of political capital, were not always - or only-implemented by regidores and direct members of the town councils but also by their relatives (Hernández 1995). This practice constituted an effort to maintain a logic of interfamilial relationships that would continue to resolve conflicts through lateral payments in the form of social promotion and that would corrode an institutional system which, by its very nature, was, according to new institutional economics, inefficient. Rent-seeking, which some historians have openly considered as corruption, was the great blight of the town councils and other institutions (see, among others, De Bernardo 1994; Cárceles 1994).

The halt in economic and demographic growth must have been one of the reasons for the reduction in the establishment of religious institutions (Graph 5.2). But the existing stock of foundations, nearly all of which had lands tied to them, and the large amount of entitled goods (a major bugbear for the arbitristas), was not reduced by an inch, and their weight now fell on an economy that was not growing or did so only very slowly. In other words, not only did they have a dissuasive effect on the development of productive investment, but they actually absorbed a growing portion of the GDP of Castile. Our existing knowledge of cases makes it clear that the religious order par excellence of the sixteenth century, the Jesuits, retained their capacity to absorb productive resources until at least 1620 or, indeed, even until $1640 .{ }^{5}$ Viewed from the crisis at the end of the century, it is impossible to overlook the avidity of the ecclesiastical institu-

\footnotetext{
${ }^{5}$ Yun (1987, pp. 334-60), Lozano (2002, pp. 91-103), Mata (1987, pp. 171-8), Brumont (1993, pp. 296-97).
} 
tions in extending their properties through purchases or the creation of censos that originated in the purchase of lands from heavily indebted peasants (Pereira 1991, pp. 84-101). Even if the demographic crisis reduced the internal pressure within the families of the oligarchies and the wealthier peasants, it is also evident that, for several decades, the ecclesiastical institutions continued to be capable of integrating into their ranks a sizeable number of members of these groups. Indeed they even helped advance the expansion of what F. Brumont called the 'peasant mayorazgos', that is to say the creation of chaplaincies and religious foundations that offered elite rural families the chance to settle a relative in them and were just one part of the broader strategies for the reproduction of the political and cultural capital of these lineages (Brumont 1993, pp. 289-99, and 32-33).

The sale of titles was also taken advantage of by new families originating in the urban patriciate, who found in it a means of access into the high nobility. ${ }^{6}$ If many of them acquired or had acquired a seigniorial estate, sometimes with incomes of a jurisdictional sort, it is clear that land income was usually the most important component in their mayorazgos. Of course, this process occurred in regions such as Andalusia or Extremadura, where the character of the seigniors as great landowners and the abundance of large latifundios went far back. But it also became more common in the Duero Valley (Yun 1987). Rather than a seigniorial (or feudal) class, it appears to have been a group of landowners, in the literal sense. And, as in previous periods, some did invest in improving their mayorazgos, even if the requests for censos to this purpose appear to have been relatively few and marginal, barely touching 7\% of the total (Yun 1999c). But, at the same time, this group was overcoming the fall in its incomes thanks to the replacement of censos (mentioned above) and by its service to the Crown, from which they acquired not only debts but also additional incomes and favours that, in certain cases, came to equal those generated by their estates (Yun 2002a).

${ }^{6}$ The advance of the number of title holders is the following:
\begin{tabular}{lccc}
\hline Year & $N^{\circ}$ de of title holders & \% growth & \% yearly growth \\
\hline 1520 & 60 & - & \\
1554 & 68 & 13 & 0.4 \\
1581 & 100 & 32 & 1.2 \\
1597 & 124 & 24 & 1.5 \\
1631 & 241 & 194 & 5.7 \\
1700 & 533 & 221 & 3.2 \\
\hline
\end{tabular}

(Atienza 1987, p. 41) 
Judged by the simplest and most vulgar gradient, the overview of these trends confirms the well-known Enlightenment view of the forms of management used by elites in Counter-Reformation Spain. Still it is worthwhile underlining that these economic strategies were not resistant to change or in any way irrational. Rather, what prevailed was a unique mastery in taking advantage of patrimonial resources during an age in which elites, like the rest of society, faced growing difficulties. They knew how to manage their mayorazgos, how to make good use of dowries, how to buy lands from peasants who were in beyond their depth, when-and when not- to free censos, and even when silver should be melted down to convert it into jewellery in view of its increasing value in respect to vellón. The land-purchase strategy employed by the ecclesiastical institutions was perfectly rational for their purposes and highlighted their intention to avoid the dispersal of plots of land (see, e.g. Mata 1987, p. 171 and Brumont 1993, p. 286). The fact that the price of the office of regidor increased more quickly than the value of land demonstrates that many buyers had good knowledge about where the best opportunities lay; but, by the same standard, the diversification of investments was very clear. We even know of efforts to introduce improvements to farms owned by the Jesuits in Villagarcía de Campos or by the Benedictine Monastery of La Espina (Yun 1987; López 1990). Of course, these measures did not keep the crisis from the door of the elites. And, worse, many of these strategies were the direct result of falls in agrarian income and prices, the declining profitability of juros, and the dip in rents paid on houses within the mayorazgo in which the temptation, though existing, of investment was not very high.

\section{A Balance}

The sense that the policies of Olivares were a total failure has created among historians a certain idea that the period was characterized by a complete absence of changes. The reasoning is logical: if the reforms failed, everything remained as before. But this line of thinking is incorrect. Many things did in fact change.

It is clear, on the one hand, that at times the arguments of Acemoglu et alter on absolutism present a reasonable view of the situation, particularly for the 1630s and 1640s. This having been said, it should be stressed that this is not really the case for Acemoglu's views on services, donativos, and other measures, as the majority of them 'were not, technically speaking, taxes that the Cortes had to approve' and were therefore acceptable on the 
juridical level (Fortea 2008, p. 249). But, certainly, Acemoglu is correct in that they, in themselves, were not particularly positive for economic development. Above all he is right in regard to the monetary manipulationsalthough rather absent in his reasoning-the seizure of shipments from the Indies, and the unilateral declarations of bankruptcy. But again, even here, it is impossible to forget that what was limiting the chances that the metropolitan economy might gain from its Atlantic empire were not acts of parasitic absolutism but rather pacts between the monarchy and the Consulate of Seville and the systematic sale of privileges in return for financial assistance.

In any case, attention should fall on the scale of resistance to Crown policies, the conflicts generated by them, and the fact that, in the heart of the empire, these disputes did not move beyond being phenomena of a purely local character. Historians have been much concerned by the (logical) question: why did Castile, the core of the empire, not witness a generalized upheaval similar to those of France or England? Certainly, there were conflicts - and many of them-but the 'Fronde' of Castile failed to become a massive and general movement. Instead it remained a bewildering and random series of uprisings, resistance, and isolated outcries of discontent. This failure to transform itself into something more substantial remains difficult to explain - this is, perhaps, always the case when it comes to saying why something did not happen in history. A posteriori, it is easy to fall into speculations, sometimes facile ones. Perhaps most important was that in 1643-the decisive moment-Philip IV chose to dismiss the Count Duke when faced with the rebellion of the duke of Medinasidonia in Andalusia, the revolt headed by Juan de Braganza in Portugal, and the insurrection in Catalonia. At a stroke, this measure removed the major grounds for complaint and perhaps ensured that additional risings were unnecessary. But if we want to speculate further on the effects of the political economy on politics, it might be possible to argue that the reformist 'acts of aggression' were bringing about a scenario in which these Frondes were increasingly undesirable. This was the case not only for the cities but also for the aristocracy and, in particular, for Madrid, where the immense possibilities offered by this empire could still unlock a flow of favours and patronage. And without Madrid-and here was the crucial difference, as Paris stood at the epicentre of the Fronde - it was difficult for the separate and isolated conflicts to coalesce into a general rebellion. By this point the Cortes - think of the leading role of the Parliament in England in the 1640s - was reasonably well controlled, and, indeed, its procuradores 
enjoyed both a certain degree of autonomy from the cities they represented and the favour of the Crown. Be this as it may, regardless of the Crown's ability to dissuade prospective rebels from rising in Castile, in the midst of this fight, the elites were sorting out their own problems or even gaining the upper hand in many battles, rendering an all-out war unnecessary. By this period, moreover, the role of the local institutions in politics and fiscal collection was proving an obstacle to the general processes of collective action. These battles took the form of isolated episodes between each city or group and the Crown, thus rendering any combined movement more difficult. Of course, one crucial element-the political culture of the day-is missing from this analysis; but, nevertheless, there are acceptable grounds for tentatively proposing these explanations for what is, without doubt, a very difficult issue.

The conflictive pact that had maintained the dominant coalition from the sixteenth century was being reformulated in many ways. It was no longer the same as it had been. The nobility had seen its military functions reborn for a while-indeed, they had even seen the traditional function of their seigniorial estates strengthened during the war with France. But the exit of Spain from the great stages of international war after the Peace of the Pyrenees (1659) made this role ever less important—at least this was the case for the old nobility - and gave rise to a change in the form of its military service. A new nobility would come to serve this function (and would consolidate its role during the eighteenth century). Rather than the mobilization of their vassals, this new system would be based on money, which allowed them to enlist and equip troops, purchase captaincies, or finance the establishment of army units in exchange for their military service; the seigniorial estates played only a very marginal role in the great majority of these cases (Andújar 2004). Although it retained its vigour in many senses, the seigniorial estate was less important in regard to military organization. The development of the colonial system itself would end up by establishing a nobility whose origins lay either in the American elites or in commerce or, very often, in both, thus changing the essential nature of the group (again, this development reached full maturity in the eighteenth century) (Yun, forthcoming). Many of these families came from the urban elite, and their relationship with the Crown would be direct and personal (Felices 2012). This would not be a corporate relationship in any sense.

The new fiscal system and, above all, the development of the donativos system with the disappearance of the Cortes-whose demise was an indicator of much more profound changes-were steps in the same direction. As set 
out above, the relationships between the king and the urban oligarchies- the need for an understanding between them-would continue to be present. The destruction of their corporate character brought about many changes, and, of course, this was important because it was altering a crucial element of the composite monarchy. This is also a decisive fact for the new institutional economics approach and the study of the political economy of this monarchy. It was to be a key phenomenon in the construction of a state that modulated a different type of conflictive pact. In this new model-without the Cortes - a financial revolution of the English style, where the role of the Parliament after the Glorious Revolution was crucial, was just unthinkable. It is also important for the historiography of political economies, which have made the revolution of 1688 the fundamental turning point (North and Weingast 1989). In Castile, the long-term evolution of the relationship between king and the elites was preventing any comparable process.

The overall result would be a system that for long periods fed the economy of legitimization and sustained the cost of a decentralized system of welfare, led by elites. This turned out to be relatively inefficient on the material level: helping the needy, preventing death and curing illness, and so on. But, as was fitting to a period and a form of Catholicism that understood welfare more in terms of the wellbeing of the soul than attending to the travails of the body, it perhaps served much more effectively as an antidote to growing discontent which might easily have manifested itself in massive conflicts. It might, therefore, serve to explain too the relatively low-in comparison with countries such as France or England-level of upheavals seen in Castile in this period.

The outcome would be the maintenance of property rights. Except for the alienation of communal and royal lands and the increasing concentration in land property, few substantial changes had occurred in the juridical nature of land property. And even these had a slow effect on the productive capacity of some zones. Moreover, in more than one case, there had not even been any sort of privatization; rather what had happened was that these lands were bought by the councils to be used henceforth solely for the benefit of the oligarchies and also obstructing any possibility for productive improvements in those lands. Privilege, in the sense of new institutional economics rather than as political prerogative, was now an important means of gaining access to wealth in a society that was closed rather than open and exclusive rather than inclusive; this was a society in which it was normal for personal networks to pervert even further the working of formal institutions, which were now very far from the Weberian ideal. 
Yet this growing absolutism was based on a system that continued to be characterized by counterweights and balances in the exercise of power. In this period pacts, and not the all-embracing power of the king, were at the base of the most inefficient side of formal institutions (in the sense established by North and others).

\section{Ruptures And Continuities: A Decadent Empire?}

Approached from the viewpoint of the political economy, it would be an error to think that the various forms of conflictive pact established between elites and the Crown were determinative in the processes of rupture and continuity that were seen in the empire in the middle of the seventeenth century. An entire historiographical current, elegantly synthesized for Spain by X. Gil (2006), has rightly argued that the problem also needs to be seen from the perspective of intellectual history and political thought. But the perspective we are adopting here can (partially) illuminate the causes of the process as well as its effects on the political economies of the epoch.

\section{Ruptures in the European Peripheral Kingdoms: Portugal and Catalonia}

As all seventeenth-century European societies, those of the Iberian world witnessed political ruptures that are crucial in understanding its skeleton and history. Not only Castile, as we have seen, but also Naples, Sicily, Portugal, Catalonia, the American colonies, and so on went through similar experiences. Here we will consider the last three cases as a way to test how the relationship between the Crown and the elites affected the empire.

\section{The Portuguese Rupture: Globalization Against the Composite Empire}

Given their coincidence in time, it is normal for the crises of Catalonia and Portugal to be studied in parallel (although seldom are they placed in any sort of comparative framework). ${ }^{7}$ There are good reasons for this, although the phenomena were very different. The crisis of Catalonia was another of the ruptures experienced by the composite monarchies of dynastic character on account of the pressure of war: Naples and Scotland, for example, followed a similar pattern. And Portugal had elements of this. But the

\footnotetext{
${ }^{7}$ See an excellent exception in Elliott (1963, pp. 489-522).
} 
causes and the development of this latter conflict provide evidence also of the difficulty of maintaining a global empire such as the Luso-Spanish one in the context of a process of globalization and upon the basis of a composite monarchy, during the period that witnessed the dawn of the mercantilist policies of the seventeenth century.

Everything began, as is well known, in 1637 with the rising of the city of Évora and the regions of Alentejo, the Algarve, and Ribatejo. The work of local nobles and churchmen, the movement was suffocated without difficulty because of the lack of aristocratic support. But its second coming was decisive. After the Cortes of Tomar, an important tension had emerged over the efforts by the monarchy to involve the kingdom in the raising and lodging of troops (Schaub 2001). This tension had grown because of the attempts to implement the Union of Arms but reached its maximum intensity when Portugal and its fidalgos and nobility, Dom João de Braganza included, were asked to collaborate in the repression of Catalonia: on 1 December 1640, an uprising occurred in Lisbon that Braganza would soon take over and lead. As in Catalonia, the conflict quickly acquired an international character, with the involvement of France, attempts to interfere in Andalusia through the duke of Medinasidonia, and the arrival of help from England (Costa and Da Cunha 2006; Valladares 1998, pp. 37-45).

The Portuguese Restoration is understood as a rupture of the pacts formed with the Habsburg monarchy. As has been said, a sizeable part of the Portuguese aristocracy had formed unions with Castilian families which allowed it access to the favours of the empire. But, in complete difference to what happened in Catalonia, the most important family of the kingdom, the House of Braganza, though it had obtained economic awards, had remained rather outside the network of Madrid Court, something that afforded it considerable freedom of manoeuvre (Costa and Da Cunha 2006). Its ties to the Castilian aristocracy-Dom João's marriage to the sister of the duke of Medinasidonia, an outsider to the court dynamic of Madrid - rather than being a balsam for his discontent, was instead a help to the rebellion. Olivares had made great efforts-perhaps coming too late-to incorporate the peripheral nobilities into the government of the monarchy (Elliott 1982, pp. 513-6). But, 'to the extent that it was reducing the role played' by the Portuguese nobility, 'the solidarity of its nobles [with Madrid] was dissipating' (Bouza 2000, p. 229). Only one Portuguese-Braganza himself-had been granted membership of the Order of the Golden Fleece (de Ceballos-Escalera y Gila 2001, 
p. 294).$^{8}$ No Portuguese noble had received the title of Grandee of Spain. If the royal favours had been fewer than desired, the Crown's attempts to revise the Ley Mental (a measure to return lands usurped up to the sixteenth century to the royal estates) were not the best antidote to discontent or, to be more specific, passivity when faced with open rebellion (Bouza 2000). Yet with all of this, the Portuguese aristocracy would remain the group most loyal to Philip IV: the revolt of 1640 produced a division within the high nobility rather than an unconditional support for Braganza (Schaub 2001; Bouza 2000). Moreover, some of the families that passed to the side of Dom João did so by a trans-frontier policy that, rather than pledge loyalty to a sole monarch, sought to maintain the interests of the houses on both sides of the border (Terrasa 2009).

As was the case across all of Europe, the rebellion had a fiscal component. In listing its causes, historians frequently mention measures which preceded the rebellion of Évora, such as the real del agua (a tax on the consumption of wine and meat), or the increase of the sisas. A number of taxes might be mentioned here: the medias annatas (introduced in 1631) was perhaps the most significant. On top of this came military mobilization after 1639 (Schaub 2001). But in reality the fiscal problem should be understood in the wider perspective of the tax systems of Portugal and Castile.

As we have seen, Portugal had created a tax state, but most of the incomes of the king originated above all in his empire, with the kingdom itself contributing very little. This remained the case until the seventeenth century, as can be seen in the budgets for 1607 and even 1621, which still maintained a surplus. The absence of costly overseas wars had prevented the development of public debt in the way that had occurred in Castile (Hespanha 1989, p. 198). But this arrangement was now unsustainable. The problems in the overseas empire meant that, from the $1620 \mathrm{~s}$, the Estado da Índia entered into a chronic deficit (Godinho 1982; Disney 2009). The reduction of commercial activity also provoked a fall in incomes derived from the overseas sector and the tolls on imports and exports. And this came at a time when defence costs were rising, something which, if not entirely the result of Habsburg policy, appeared to be the fault of Madrid to many Portuguese. All in all, from the third decade

\footnotetext{
${ }^{8}$ The honour was conferred in 1581 upon the sixth duke, Dom João de Portugal. His grandson, Dom João de Portugal (the eighth duke), was also made a member of the Order, although this would subsequently be annulled in light of his rebellion (de Ceballos-Escalera y Gila 2001, p. 341).
} 
of the century, a historical change occurred, one unknown to the Portuguese: if until then a substantial part of the Portuguese Crown's expenditure had been afforded by the king's imperial revenues (Chap. 4), now the kingdom, and not the king, had to increase its contribution to the budget, deal with debt, and face growing military costs. The increase in prices, which devalued the income of the Crown, meant a doubling of these efforts (Hespanha 1989, p. 112). So the Union of Arms, in which Portugal was assigned responsibility for 16,000 soldiers, not only endangered the treasured principle of the 'kingdom's resources for the kingdom' but was also accompanied by a breaking of the rules of play between king and kingdom. To all of this can be added that, through a number of new forms of behaviour, Castilian interests were increasingly interfering in Portugal, creating notable conflicts of competence and jurisdiction (Schaub 2001).

It would be an error, nonetheless, to see the rebellion only from the perspective of the Iberian Peninsula. Its origins lay in the combination of a composite monarchy of many states and a global empire that characterized the monarchy as a whole. This is the principal difference with Catalonia, Naples, or Scotland and what gave the events in Portugal their specific and unique character.

Historians have usually placed emphasis on the political discontent with Madrid Court that, according to many Portuguese, governed only in line with the interests of Castile. The failure to defend Ormuz and the ridiculous campaign led by the Count of la Torre to save Pernambuco in 1638 further advanced these arguments (Elliott 1963). But, in reality, what lay behind all of this were problems that were more difficult to resolve.

One of these issues derived from the need to mobilize resources on a global stage that, to all extents and purposes, compelled the monarchy to undertake combined and complementary actions such as the recovery of Bahia. The drawback was that mobilizations of this sort were very difficult and were not always undertaken without problems. In fact, Castile complained of having to employ its funds in defence of Portuguese interests (Borges 2014). But the Portuguese, for their part, could take this problem as far as schizophrenia. Not only were they worried about the movement of resources out of the country to defend Castilian interests but also that help from Castile could lead to mistakes that might lead Castilians to make some claim upon Portuguese domains. The polemic on the 're-conquest' of imperial territories taken by the enemy and a 
number of actions such as those in Asia in these years are highly significant in this regard (Cardim 2014; Valladares 2001). The appointment of Castilians to colonial offices, as happened in Maranhão (Schwartz 1964, p. 41), could only increase these concerns.

The abundance of cases in which the interests of Castilians and Portuguese appeared to be in opposition moved things in the same direction. Certainly, the intertwining of both empires was more than evident. But from Pernambuco (Schwartz 1973) to the Río de la Plata, to the Chinese Sea, scenarios were created in which this relationship could lead to conflicts between imagined communities of Portuguese and Castilian or, simply, appear in this light and be transferred to Madrid or Lisbon in their most problematic forms (when neither Madrid nor Lisbon was creating these issues). In this way the mingling of Portuguese and Castilians in colonial spaces was producing a surge of feelings about imagined communities existing on top of one another. A point of convergence was found in the condition of both peoples as Catholics, which led one observer from Madrid to argue that they had the 'same nature' (Elliott 1963). But these communities came into conflict with one another to the extent that each also created itself through opposition to the other. This is not surprising if we take into account that it was in the colonies, perhaps more than on the Iberian Peninsula itself, that the seeds of imagined communities that increasingly defined themselves as Portuguese and Spanish were sprouting (Bernal 2007, pp. 324-325; Herzog 2015). The way that histories of Castile (ever more closely identified with Spain) and Portugal proliferated in this period underlined the apparently contradictory nature of the two states and was a good symptom of this change (Cardim 2014). Such evidence reveals how the empire and the tensions that ran through its heartlands generated and reinforced imagined communities that were suffocating the empire's very principles.

This clash of interests-or the way that elites, in both Madrid and Lisbon and the overseas territories, conceived of them-did not only affect the colonial world but also the relationships between it and Europe. The Portuguese found it difficult to understand the prohibition on trade with the Dutch, which meant that the salt trade with the Low Countries, which had sustained their international commerce from the fifteenth century, was now classified as contraband (Schaub 2001). Equally the critical phase of the war, which obliged Madrid to concentrate forces in Europe, was hardly compatible with the state of permanent attack in the colonies, where Portugal faced powers which by now were practising a purely mer- 
cantilist policy. If Portuguese perception was that the war in Flanders after 1621 had drawn attention away from Brazil, the outbreak of war with France in 1635 would only accentuate this feeling of suspicion. This situation was worsened to the extent that the defensive system, which was more effective in the Spanish colonies, deflected Dutch attacks towards Brazilian colonies, the weakest point militarily and also a very interesting one economically. If this were not enough, from the very beginning, the conflict between the Habsburgs and Portugal had a global root: if the war efforts imposed by Madrid's strategy were exhausting, in reality it was the decrease in colonial income from the Estado da India that rendered unviable a system that until this point had been more or less effective. Such factors went far beyond the Madrid's incapacity to resolve Portuguese problems - or, indeed, any insensitivity to them. This was a structural problem and one very difficult to resolve.

In this world of opposing interests, with an empire faced with enormous problems of regulation and arbitration, with expensive, slow, and asymmetric information, globalization-manifested in the intervention of outsiders into what the Spanish and Portuguese Courts understood as a monopoly-presented a daunting challenge. A river of ink has been spilt to try to justify the policies of the Habsburgs by the aggression of the English and Dutch against the Portuguese empire. But, can anyone really imagine Dutch merchantmen moored in Amsterdam waiting for permits to trade with a world-beginning with the Portuguese empire-that, as Grotius himself said, should be open to all countries? And, did this not mean, in any case, a peaceful and inevitable invasion brought about by infiltration into the very Portuguese monopoly and the system of licences?

In this way globalization, a multipolar phenomenon by definition, was an obstacle to keeping the two empires united. The composite and dispersed character of the monarchy moved things in the same direction. And together these things created a lethal combination that could only have been overcome-and even then it is debatable if any such programme could have been successful-by profound reforms in the political constitution of both kingdoms and their empires.

This global dimension of the composite monarchy was not only present in the causes of the conflict but also in its development. It is well known that the beginnings of the conflict had a multipolar and global character that was manifested in areas from Brazil to Angola, from New Spain to Cartagena de Indias and even Ceuta, Tangier, and as far as the coast of lower Andalusia (Valladares 1998, pp. 31-45). It has even been said that the rebellion began in 1634 in Asia, with the disobedience of the viceroy 
Linhares, who, taking advantage of distance and the slow movement of information, refused to obey Olivares in the matter of agreements with England (Valladares 2001, p. 56). And this list does not include the confrontations in the Río de la Plata, the Philippines, and many other areas of Asia. Portugal's victory also had a great deal to do with the global dimensions of its empire, which quickly became a temptation that England could not resist, seeing in these dominions an area of potential indirect influence; London's help would be decisive in achieving independence from the Habsburgs and for the recovery of Pernambuco from an enemyHolland-which in principle was much stronger (Boxer 1957). This same attraction would explain the marriage of Barbara of Braganza, the new monarch's daughter, to Charles II of England, which would seal the antiHabsburg pact. The empire's multipolar structure also proved decisive, as revealed by Salvador Correia de Sá e Benevides' expedition from Brazil to seize Angola from the Dutch at a moment in which the peninsular war against the Habsburgs was decisive (Costa 2014, pp. 191-3). And, at the same time, the empire proved decisive in that it became money of exchange for peace with Holland (in the treaty of 1661-1663) when it was most necessary to concentrate forces on the peninsula against the Habsburg troops (Costa 2014, p. 208). Equally the victory of the Portuguese must be related to the Juan de Braganza's capacity to attract, over and above the attacks of the Inquisition, the financial help of the global networks of conversos and Portuguese Jews, at precisely the moment when the Spanish bankruptcy of 1647 brought to light the ill will and rancour towards them felt in Castile on account of their status as bankers and Jews (Sanz 1988). On the side of Castile, this was a demonstration that an informal and global network could - in specific circumstances-become a factor in the dissolution of political ties that it had attempted to restrict through the control of formal institutions.

As we have seen, at the heart of the matter stood the high degree of decentralization exhibited in these networks' economic and social organization. The combination of both characteristics, and the presence in them of actors with very different agendas, meant that it was very difficult for political power in Madrid to control them. One group of Jewish converts, for example, was able to adopt positions with totally different political effects in Madrid, Lisbon, or other parts of the empire-indeed, sometimes just one individual member of them was able to do so. This fact explains - in this case economic rationale had a lesser role- the case of the Jesuits, who were able to adopt political positions that, if well negotiated 
and never free of cost, were very different. In Asia, for example, the Jesuits supported the Portuguese side with no embarrassment (many of them being Portuguese in origin), while in America they fell on the side of Madrid. The only options for this empire were either disintegration or a high degree of negotiation and autonomy of the different nodes of these networks. And the outcome of these tensions could only be the split of the two imperial formations.

\section{The Catalan Crisis or the Problem of a Composite Monarchy}

In Barcelona in 1640 a rabble of harvest workers stormed the city, and the rebelling inhabitants were able to take control of it. In May 1652 groups of unemployed harvest workers from Galicia broke into the cities of Córdoba and Seville and sparked an uprising of the people against their governors and patricians. Although a part of the urban oligarchy and the well-off initially participated in these tumults, they then would suffocate the upheaval. The Barcelona revolt ended with the death of the viceroy Santa Coloma and was the opening of a civil war led by the elite of Barcelona and the Generalitat.

Neither conflict can be explained only by the attitudes of the urban elites. It would also be an error to look upon the Catalan elites as a counterpoint to their Castilian peers. Notable parallels can be found between these groups: their desire to control municipal life, their capacity to reach agreements with the king for the maintenance of order, the interest of some families to enter into the client networks of the court, and their use of dowries as strategies for social reproduction and similar practices (Torras 1998; Amelang 1986, pp. 86-91). Both groups had common aims and customs: the same affection for rentier incomes, their investment in public debt or in social and political capital, and their desire to marry into noble families, their use of ecclesiastical institutions as a means of reproducing family relationships. A careful reading of Xavier Torres' work demonstrates that all of them needed to promote their members and to give an outlet to their needs for social expansion (Torres 1994, pp. 201-23 and 234-40). The Catalan succession system, based on the here $u$ in which the main body of the inheritance passed to the eldest son, only increased this need. Many of these traits-with the exception of the inheritance system-were present in Castile and across Europe and, of course, throughout Mediterranean Europe (Delille 2003). Yet this does not mean that there were no differences in degree that, as we shall see, would have considerable importance. These differences were also condi- 
tioned by the different forms of relationship between elites and the monarchy and were mixed with the existence of differing constitutional practices and traditions. These points of divergence were superimposed upon other differences such as language, whose importance can never be overlooked, and even a process in which separate imagined communities were formed that in part owed their origins to the impression-confirmed by later research - that Castile was attempting to advance a growing sense of identification between the concepts of Spain and Castile. ${ }^{9}$

By 1585 the expansive wave of Catalan commerce appears to have reached its temporary ceiling. Catalonia's role as an important route for the dispatch of money towards the Spanish road had positive effects for the country's economy. But the difficulties of the Castilian fairs very possibly affected the Catalan merchants' capacity to introduce their products in Castile and even in America and reinforced the need to recompose the commercial networks towards cabotage trade in the Mediterranean (Elliott 1982, p. 52; García Espuche 1998). This was happening at a time of competition from products from other countries in Seville and in particular those channelled through the Consulate into America, which also went against the interests of the principality-and, of course, those of the industrial cities of Castile. As P. Vilar said, the decades that preceded the rebellion were not marked by economic crisis, as a recovery had occurred. But the Catalan economy gravitated less towards Castile than it had in the sixteenth century.

The progressive distancing of Catalonia from the Habsburgs, however, was not brought about by purely economic factors. In the Cortes of 1585 , the fundamental conflicts came to light: on one side, the conflict between the king and the Generalitat, which Philip II sought to reorganize and control; on the other side, the Catalan claims to limit the number of familiars of the Inquisition and restrain the institution's power. The oligarchy of Barcelona, which at the beginning had been one of the closest sectors to the monarchy in Catalonia, found itself from 1586 in an open clash over the naming of ciutadans honrats (honoured citizens) which, far from daunting the Crown, led it to make a series of scandalous appointments. And, if a compromise agreement was eventually reached, an important short-term tension occurred (Amelang 1986, pp. 46-62). This came at precisely the moment when the Catalan Cortes increased their

\footnotetext{
${ }^{9}$ Elliott (1982, pp. 42-7); Simon i Tarrés (1999). For the idea of Spain as an extension of Castile, see Thompson (2005) and Cardim (2014).
} 
contribution to the king (500,000 libras in 1585 and as has been said $1,100,000$ in 1599) and when they came to normalize the payment of the quinto, a tax on the fifth of taxes and municipal sisas (Hernández 1996, passim). In a country that had managed to maintain the principle that each kingdom should meet its own costs, the Union of Arms would be rejected by force. And the exasperation and rudeness of Olivares when faced with the slow proceedings of the Cortes would add fuel to this fire (Elliott 1982). In this context, during the 1630s Philip IV had preceded to the massive sale of positions of ciutadans honrats (Amelang 1986).

But, above all, the conflictive pact between the Catalan elites and the monarchy was different to its equivalent accord in Castile. Certainly, the great noble families - the Cabrera, the Cardona, or the Requesens-had formed solid ties with Castilian and Valencian families and, by this route, with the Crown. Absorbed by - and at times secondary within - the great Castilian lineages, some of these houses would be closer to the court and the king than to Catalonia's internal problems. And there was no shortage of patrician dynasties, such as the Franquesa, that managed to prosper thanks to their ties to the Court in Madrid. But the economic difficulties of the provincial nobility and their problems in reproducing their lineages, manifested in banditry (Elliott 1990, p. 117), provide evidence of their more problematic integration into the empire's patronage system and, consequently, the relative difficulty of this group in thereby achieving its social survival and promotion. It is very significant, for example, that only 14 of the 1400 members of the Military Orders in 1625 were Catalans (Elliott 1963, p. 74). This fact not only marked differences in respect to Castile but also to Aragon and, above all, Valencia, where the Military Orders and the presence of the mid-ranking nobility in them had been very significant. Various similarities existed between the elites of Castile and that of Catalonia, which played a vital role in the conflict of 1640 . But, to an extent that was unthinkable in Castile, the Catalan elite was made up of lawyers and university graduates who had mixed with the semi-urban, mid-ranking nobility that was also increasingly university educated (Amelang 1986). This gave the elite economic independence and, more important, a type of constitutional vision of politics that sat badly next to the sort of absolutism that Philip IV and the Count Duke were so keen to promote.

The Catalan fiscal system, much less efficient in tying Crown and county than its Castilian equivalent, had not created a clear integration; nor had it forged as solid a conflictive pact between the king and urban oligarchies. 
A part of the oligarchy of Barcelona had subscribed to the censals emitted upon the tax system of the city to pay for the king's debts. And the same had happened at a lower level in many towns of the principality (Elliott 1963, p. 139). But the independence of the Diputació with respect to the king, its 'dubious financial actions' (Elliott 1963, p. 141), and the temporary character of the services had prevented the Principality's tax system from becoming a continuous and systematic support for the debts of the king. It was impossible to imagine in Catalonia a single city becoming a 'pensionopolis' - a fount of pensions and offices - that, according to Fernández Albaladejo (1992), had been crucial for the fiscal pact between the king and kingdom (1992) in Castile. And it was also impossible to conceive of something of the proportions of the accord over the collection of the alcabalas or the millones, upon which the same pact had been established in Castile. As has been said, the very system of setting censos on mayorazgos, so important in binding nobles to king in Castile, functioned differently throughout the Crown of Aragon, where royal permission was not necessary (Abadía 1998). In certain circumstances in Catalonia, favours and privileges were granted to elites. Above all, this was done to continue or prolong the meetings of the Cortes. Nor did the Catalans entirely fail to secure appointments to positions in the administration. But the monarchical state was not as developed as in Castile and nor, therefore, was the scope for patronage and clientele arrangements. With the great offices and favours of the empire in the hands of the Castilians, the prospects of the Catalan elites were more remote, except for those members of families (mentioned above) belonging to the highest branches of the aristocracy (Vilar 1962, vol. I, p. 368; Molas 1996). In other words, the political system was much less efficient than in Castile at creating conditions that would have allowed the empire and the composite monarchy to become the solution to the dominant coalition's social development and expansion. On the contrary, the destabilizing effects of absolutism would make themselves felt (see Chap. 4).

The pressure exerted by the duke of Alcalá on Catalan towns, with the billeting of troops and the other measures introduced by Olivares, broke the previous pacts. Despite the Cortes refusing to back the Union of Arms, Catalonia's contributions to the defence of the monarchy also increased, as we have seen (Bernabé 1993). The sense that the Crown did not carry out its fundamental duty to control banditry and maintain order came to add to the negative effect of the devaluations of Castilian money that circulated in considerable quantities in Catalonia (Elliott 1963, Chapter 3). Yet the conflict that was unleashed in 1640 was much more than the sum 
of these parts and cannot be explained solely from this perspective. It had deeper political and even cultural components whose origins lay in traditions and also, importantly, in language. But, fundamentally, the political economy that created this weaker variant of the conflictive pact lay beneath these uprisings of 1640 . This view can even in part explain the solution to the crisis. Catalonia - and above all its governing class-was divided into supporters of the French Bourbons and the Spanish Habsburgs. And after 13 years of war, the problems of both countries brought about an agreement that led to the domination of the latter over the principality. The conflict was very expressive of something shared with the Portuguese case: the mixture of civil war and international conflict found in both episodes.

What followed lies beyond the scope of this study. The result would be a very unstable conflictive pact between the Crown and the elites. Above all, the tension continued to manifest itself in the fight over the system for confiscation and the return to previous levels of self-government (Simon i Tarrés 2011, pp. 61-97). But it also resulted in a process of drawing together that passed through the renovation of a group of 'honoured citizens' of Barcelona thanks to the king's appointments, as well as those of the local aristocracy itself (Amelang 1986) that, if it did not lead to a total agreement with the Crown, at least put in place better bases for it andaccording to some authors-even led to a greater presence in Madrid (Soldevila 1962; Vilar 1962).

From the perspective of this study, the differences with Portugal have a heuristic value. Both conflicts took an international character. Quite possibly the insertion of Catalonia and Portugal within Castile's social and economic life was to a similar degree. The benefits their elites received from the Spanish empire were also very limited in both cases. The elites of both countries had developed a sense of imagined community based on a linguistic distinction and so on. But Catalonia, without an empire, was less attractive to an exhausted France, than Portugal was for an England which, coming out from the ashes of the revolution, increased its aspirations over a very promising Portuguese empire. Catalonia lacked the international imperial webs almost impossible for the Habsburgs to control and which even allowed for expeditions like that of Salvador Correia de Sà. Nor had it the possibilities of obtaining international support in exchange for privileges and trade concessions, such as those obtained from the Dutch in 1661-1663, which allowed the monarch to concentrate forces on the peninsula. In part as a consequence of such factors, Catalonia could not even dream of dynastic alliances like that of Barbara de Braganza and Charles II. 
It is impossible to know if, having met such conditions, Catalonia would have become independent. Furthermore, many more differences could be added. But reasoning in this sense helps to better understand to what extent globalization, again, was influencing the live of Europeans and more in particular of the Portuguese.

\section{The Renewal of the American Colonial Pact}

\section{A Renovated and Difficult Agreement}

The American colonies provided the opposite case to Catalonia, Naples, and Portugal. Here there were also confrontations. But, far from leading to a general rupture, a series of pacts was set down in depth and in the creation of a space of understanding with the Crown.

Until almost 1570 the general American fiscal burden, leaving aside the quinto of the mines, had been relatively light (Chap. 2). But the military commitments in Europe and the costs associated with the construction of the colonial state rendered the incomes from the mines insufficient and forced Madrid to try to increase its fiscal demands. The measures employed to this effect were to be the same as, or very similar to, those used in Castile and implied a relationship with elites that was formally very analogous. This led to the increase of the alcabalas, to the sale of wastelands and public offices and the introduction of the media annata (again, a tax on the succession to offices) and similar measures, the majority of these being part of bargaining with the colonial elites. To mitigate the increase in the alcabalas and the imposition of new tax burdens, the cities were given the chance to oversee their collection and management through the creation of sisas (Amadori 2012, pp. 10-15), something which, as in Castile, strengthened the power of the oligarchies and created areas of agreement with the Crown. ${ }^{10}$ The same could be said of the creation of juros, to which the oligarchies subscribed (Adrien 1981). The municipal authorities even recurred to the seizure of Indian possessions to swell the cajas that, it was claimed, were to be used in the defence of the weaker areas of the empire (see below and Moutoukias 1988). They also developed the system of donativos that, as we have seen, was a form of exchanging resources in money, men, or equipment, for economic and political privileges (Amadori 2012).

\footnotetext{
${ }^{10}$ For a more specific list of the areas of fiscal income in America, see both TePaske (1983) and Amadori (2012, pp. 19-23).
} 
Things were not, however, confined to fiscal level. In difference to Castile, the Crown did not yet recur to the sale of titles and jurisdictions. But the rhythm of legitimizing alienated lands (composiciones de tierras) continued or even increased, as did the granting of property rights to society in general and to the elites in particular. As Ruggiero Romano has shown in his excellent study (2004), the way that these grants were conferred meant that the Crown became the final guarantor of property rights. In this way, from the end of the sixteenth century, the emerging elites bought large tracts of land with which they established the great ranches of Mexico or the sugar or tobacco farms, to give examples from New Spain. And the same happened in Peru. Moreover the process of granting mining rights continued (Bakewell 1990, 1991).

On top of all of this came similar deals with the merchant and financial elites. The great traders of Lima and Mexico benefited from privileges to continue to feed their growing economic resources with this political capital. As we have seen, the Mexican elite involved in the Consulate were able, with the support of the town council, to secure advantageous accords with the Crown in exchange for money. Cases of this sort are very expressive of the type of practices that lay at the basis of this relationship. And similar practices can be found in the fiscal negotiations between the Consulate of Lima and the Crown (Gasch 2015a; Amadori 2012).

The development of colonial society brought about important changes in ecclesiastical organization. America-or the zones of greatest Spanish presence-became full of parishes, ecclesiastical councils, archbishoprics (five), and dioceses (thirty, plus four in the Philippines); these were allocated important sources of income: lands, tithes, and even industrial establishments in some cases. On top of this there were, from an early stage, charitable foundations and piety projects, confraternities, and other ecclesiastical institutions in whose government laymen played a very prominent role. And these were very wealthy institutions. In addition, an expansion of the religious orders took place from the moment of conquest itself. The evidence of this process (see, e.g. Céspedes 2009, pp. 250-63) can be used in an interpretation that comes close to the one presented here for Castile (Kicza 1999). The transposition into America of an economy of legitimation similar to that of the Iberian Peninsula fed these foundations and their growing wealth thanks to donations by elites. These endowments were the result not only of cultural beliefs very suitable to the political economy of this society, but also, and as in the peninsula, these institutions were soon to become an area into which elites would expand, 
one offering an outlet to many of their members. This development turned the Church into a 'less indigenous' institution, but it certainly did not reduce its enormous power over a population where Catholicism, often highly mixed in with older beliefs, exercised great influence (Céspedes 2009). It was precisely its proximity to the lowest ranks of society that gave religion its enormous stabilizing power upon the social system. But this is better understood if we take into account the notable control exerted by the Crown over ecclesiastical resources (Elliott 2006, p. 205).

The Church was also key to establishing and maintaining a certain social order in a world of enormous internal differences. But it was not the only factor. The Leyes Nuevas had created a framework in which the rights of the Indian were theoretically recognized. The establishment of Indian rural communities and towns enjoying a certain degree of autonomy and which, despite the usurpations, retained control over common lands (Coatsworth 2008) operated to the same effect. So did the recognition of misappropriated lands which, if elites took the lion's share, also benefited the lower echelons of society (see the figures given by Romano 2004, pp. 88-90) who, in this way, came to see the Crown as a guarantee of their claims on their possessions. And from the end of the sixteenth century, property rights were guaranteed increasingly by 'the application of Spanish laws' rather than by registers dating back to before the conquista (Elliott 2006 , p. 203), thus tying them all to the king's decisions and creating dependence and loyalty. In the end, the possibility of flight, a common practice given the difficulty of controlling America's enormous spaces and huge range of available resources, acted at the same time as a safety valve against uprisings among the lowest levels of that society, be they Indians, slaves, mulatos, or any others.

The consequences of this conflictive pact in the colonies were not confined to the strengthening of the ties with the Crown and internal stability. We should also think of it being set down upon other values, among which religion - in opposition to the Protestant faith of the enemy-must have played a highly important role (Schwartz 2008). But, above all, the immediate consequence was the social amplification of the reproductive capacity of the elites. As in the Iberian Peninsula, the opportunity to move and circulate its members from the Church to commerce and administration and so on, and to provide an outlet to tensions, was established in its heart. It also offered them the chance to maintain their multi-functionality and to circulate different forms of capital within these networks which, at times, were dispersed in space (Chap. 7). What had been established was, 
moreover, for the moment a much more flexible elite than that of the metropolis, where the prejudices of honour, for example, were much more evident. As a result of all of this, America would be an immense space for the use of political, economic, and social resources, marked by a high degree of social mobility among the elites that could, in this way, satisfy aspirations for promotion with considerable ease and thus avoid the social and political ruptures that aborted institutional development and secured the prevailing political economy. ${ }^{11}$ This process, at the same time, being based on vertical negotiations between the Crown and very dispersed and diverse groups, contributed to maintaining the empire's poly-nuclear character.

The colonial pact was not based only upon the hierarchical relationships between the Crown and the American elites. A system of interregional co-responsibility developed that strengthened the defensive capabilities of the colonies and, therefore, property rights when faced with other powers. In this way a step forward was taken in the organization of monetary flows between the different treasuries or cajas (Chap. 2). And, from the end of the sixteenth century, the regions of special sensitivity in the colonial defensive system, such as Puerto Rico, began to receive growing quantities of silver from other parts of the empire, such as New Spain (Vilar 1974; Pacheco 2012, pp. 115-24). The same was happening in other areas of strategic importance, such as the Philippines, where the figures are also highly indicative of how until 1645 defensive costs far outstripped all others (Alonso 2012, p. 282). This capacity to move sums in imperial circuits without many juridical problems, which constituted a fundamental difference in respect to what was happening in the European states of this composite monarchy, has been considered as the 'secret of the empire' or, put in other words, the key to its long survival (Marichal and von Grafenstein 2012).

Behind these developments was the growing decentralization in the use of imperial military resources and in the development of the local militias mentioned above (Chap. 7). These military efforts, which resulted in a high degree of local autonomy, did not prevent the capture of small islands in the Caribbean, and particularly in the West Indies, by the Dutch,

\footnotetext{
${ }^{11}$ One of the consequences of this situation lay in the enormous capacity of certain families of the Latin American elite who, being denied mechanisms for the preservation of their lineage and memory similar to those of European aristocrats, were in many cases able to survive until today.
} 
English, and French, some of whose settlements would be recognized by Spain in the Treaty of Munster and then the Peace of Westphalia of 1648 (Céspedes 2009, map XIV, p. 277). But this form of decentralized military organization most definitely was one of the reasons - if not the only one, as we shall see-that prevented these European rivals from bursting into America and achieving control over huge dominions in the continent, as had happened at Pernambuco.

The colonial system had arrived at a status quo that would only gain strength and be further consolidated and reshaped in the following decades.

The relationships between the metropolis and the American elites had been consolidated. Despite there being some anti-fiscal movementssuch as the revolt of Peru in the 1590s-a long series of local tumults and even a permanent situation of structural conflicts and of tensions within the elites, as in the case of México (Israel 1975; Ballone 2017; Álvarez de Toledo 2011), and many movements of resistance, nothing similar to the Catalan, or Portuguese events, happened in America. ${ }^{12}$ There existed a sort of equilibrium that constituted a variety of the prevailing formula in Castile and in which tensions but not generalized rebellions were the norms. This is not to present a narrowly materialist interpretation of the reasons for the support and loyalty of American societies to the Crown. If recent views that underline the colonial pact from the perspective of the political economies have a fault, it lies in that they overlook the enormous importance of ideological factors that were implicit in it. They focus overly on demonstrating how this pact was also the result of a political economy that, as is generally recognized today, was based upon bartering and negotiation. ${ }^{13}$ As in Castile, this relationship between elites and the monarchy lay upon transfers of immense volumes of economic resources and social and political capital in both directions. The result was a collection of accords and pacts with corporations and social groups who, without having a common representative body before the king similar to the Castilian Cortes, were arriving at an entente with Madrid. They had

\footnotetext{
${ }^{12}$ We still need a general study on the very complex social and political upheavals in Latin America which offers a typology and interpretation, but the reader can find a fast synthesis in Bennassar (1980, pp. 221-252).

${ }^{13}$ The phenomenon has been very clearly set out for the eighteenth century (see, among others, the works of Grafe and Irigoin 2012). Here our interest focuses on showing how the empire arrived at this situation.
} 
established property rights over lands, mines, and even privileges in the use of political and fiscal resources that together conferred autonomy upon the American oligarchies. These same property rights and privileges afforded them a degree of security that raised the opportunity costs or the risks involved in any break with Madrid or drawing closer to other powers. Part of this accord was also based on the practice of turning a blind eye to smuggling and to the increasing presence of forced labour-camouflaged under different formulae-in America. This is not to present a cynical vision of the actions of elites but merely to show that the political economy of the empire would be one important component of its longevity.

At the same time, the investment in the military and protection system had been strengthened, thus assuring these elites of a certain level of confidence in relation to any possible attack by outsiders as well as a coercive system that, should the need arrive, would serve to maintain the colonial order. If such defences were not enough, the foreign powers that employed highly aggressive mercantilist policies had been able to seize enclaves that did not entail high protection costs and from which it was very easy to organize contraband with Spanish colonies. For the reasons we have explained, it was better for Amsterdam, London, and more and more Paris to infiltrate the empire rather than conquer it. The peace treaties signed in 1648 and afterwards consolidated this situation. Concessions such as the settlements in the West Indies, the asiento on black slaves to England, and so on would be, as 'legal smuggling' had also been, the recognition of a fait accompli that would frame the history of both the empire and Spain itself. The system guaranteed not only the longevity and political 'loyalty' of this empire-but also its economic consequences and specific place in the history of the empires, as we shall see.

\section{Ecosystems, Globalization, and Plenty Versus Formal Institutions}

This very delicate and unstable scheme was able to maintain itself thanks to one other fact: economic growth. This development may appear even more eye-catching to the extent that, as we have seen, a sizeable number of the institutions the Spanish implanted in America were scarcely conducive towards it. At least this is the case when viewed from the usual perspective of institutional economics (chapter 7; Coatsworth 2008).

Certainly, the economic history of Latin America has been viewed as a failure. And this impression, logically, has been extended to its capacity to generate economic growth. The more empirical forms of research have, however, pointed in another direction. In R. Romano's excellent compari- 
son of the 'crisis of the seventeenth century' in Europe and America, it became clear that the iron century was not, in comparative terms, a period of recession in the American economy as a whole (1993). The same author has also provided additional proof to support his thesis, as well as further in-depth explanation of it (2004). Similar conclusions have been reached by Arroyo Abad and Van Zanden (2016), using more refined - and riskycalculations. ${ }^{14}$ Taking both works together, it is fair to argue that, within regional differences, the American economy regained a path towards growth from the end of the sixteenth century, and this phase lasted until at least 1630-1640. After the establishment of the plantation economy, the boom in urbanization, and the intensification of regional economic circuits (Chap. 7) and despite a brief crisis of uneven regional impact, from 1640-1650 onwards, practically all indicators point towards (moderate) expansion. As a matter of fact, population figures in 1700 were higher than in 1600, in spite of the mid-century problems. ${ }^{15}$ This is also reflected in the demographic recovery, due as much to internal factors as to migrations, within which an important role would be played by the forced movements of people associated with the trade in slaves (Romano 2004, pp. 63-7).

What were the reasons for this expansion, which came into its own from the midpoint of the century? In reality, rather than be a continuation of previous trends, it must be seen as a series of regional impulses with widely diverging roots. To understand it in its general framework, it is necessary to begin, to my mind, from various assumptions that acted in combination: (a) the limited impact of formal institutions-state institutions, if you wish-on the assignation of productive factors in an economy in which informal economy was so much developed, (b) the enormous abundance of resources per person derived from new regional ecosystems after the dramatic demographic recession of the sixteenth century, (c) the scope to put these resources to use through the introduction of European technology, and (d) the positive impact that international commerce and globalization would have in this context.

As we have seen, forms of property, the importance of forced labour regimes, the fragmentation and limits of the juridical system, the scope for using private violence, and so on appear in principle not to be very

\footnotetext{
${ }^{14}$ I must thank the authors for providing me with a copy of this study before its publication and allowing me to cite it.

${ }^{15}$ Following Romano's reconstruction of the figures, the population of Latin America had passed from 10 million in 1600 to 11.8 in 1700 and 19.3 in 1800 (Romano 2004, p. 61).
} 
conducive to economic development-at least, this is the case from any perspective based upon the new institutional economics. ${ }^{16}$ But in a territory as immense as Latin America, benefitting from such a positive relationship between resources and population, the (negative) effect of these institutions would have to be, necessarily, limited. ${ }^{17}$ If the capacity for enforcement wielded by state institutions was reduced, then so was their scope for negative effects.

The collision of ecological systems had led to the destruction of the original ecosystems. But the result was the triumph of new variants drawing from a wide range of resources: large unpopulated zones belonging to no one (outside, therefore, of the property rights that appear to have been so negative for economic development), enormous herds of sometimes semi-wild livestock, thick and rich woods, minerals that could be readily exploited, and so on.

The primary sector underwent important changes. One of the most significant was the use of ploughs and agricultural iron tools of European origin, water mills, and other inventions whose effects remain unstudied and, therefore, unknown. But perhaps more eye-catching was the diffusion of mules as a beast of transport and burden. ${ }^{18}$ According to Romano's calculations, in the eighteenth century, these would reach an animal-perhuman ratio that was more than double the European level. This provided a source of exosomatic energy whose overall impact upon the productivity of work would be double that in the Old World. But, in addition, an outcome would be seen in forms of 'livestock breeding' that were not only based upon inexhaustible supplies of land (very often belonging to no one) but also on hunting and the herding of wild livestock for sale, as occurred in the Argentinian Pampas, to give just one example. Progressively the ecosystems destroyed by 'ecological imperialism' were substituted by others in which wheat was extended (and, little by little, the vine), as were sugar, cacao, tobacco, coffee, and many other products closely tied to

\footnotetext{
${ }^{16}$ To use Coatsworth's words: “as in most premodern states and empires, however, Iberian institutions were not designed to promote factor mobility, technological change, or frictionless transaction" (2006, p. 256).

${ }^{17} \mathrm{It}$ is worth remembering that we are referring to a surface area of some $19,197,000 \mathrm{~km}^{2}$, that until 1492 had supported a population of between 30 and 50 million (Livi Bacci 2008, 3-19).

${ }^{18}$ The phenomenon also gave rise to the development of a mule market of transcendental importance and trans-regional in scope, as Sempat Assadourian has shown in some of his studies (1982, pp. 18-55).
} 
globalization. And there even took place a development in the use of products originally from America, such as the evergreen tree, maize, or the cassava tree, whose expansion European agents facilitated (Garavaglia 1983; Saldarriaga 2011).

The impact of these advances was not only felt in what can be called (according to today's classification) the primary sector. The expansion of the sugar industry, for instance, was also made possible by the chance to dedicate extensive land areas to graze the oxen and beasts of burden employed in these farms. But, in addition, the dynamism of this sector would be vital to the technological improvements. The expansive rhythm of the construction of windmills is proof of this, as is the diffusion of many of the Brazilian advances, such as the use of three vertical cylinders or the system of cauldrons for cooking (Gómez-Galvarriato 2006). Thus the existence of forced labour - and even the prohibitions that existed in some areas of Spanish America against it-did not necessarily abort productive expansion or technical improvements. The industrial growth was also seen in the textile sector and made evident in the development of the obrajes. These were workshops designed for large-scale production, based on the vertical integration of the distinct phases of production and represented an important advance on the production in small workshops that predominated in the Iberian Peninsula (Miño 1991). Their spread is evident between 1580 and 1630, both in New Spain and in Peru, although from this point they entered into crisis in the first of these areas and stagnation in the latter (Miño 1991, pp. 135-41). Even if they appear not to have led to continuous technological improvements, this was clearly a sector that also progressed despite being predominantly based upon forced repartitions and forced labour as a form of debt payment. ${ }^{19}$

Other important industries of the period, such as construction, are also highly significant in this regard. The sector played its part in a notable development between 1580 and 1630-1640. This ran parallel to the development of urban life (Kagan and Marías 1998) and the advance of religious institutions, whose vitality in building has been measured (Van Oss 1976). And this in turn was tied to the great cycle of the mining economy, the increase in the waves of immigration, and the branching out of elites into the ecclesiastical sector. The economic recovery can also be related to the diffusion of European building techniques and was undertaken despite the predominance of semi-forced salary systems, such as work to pay for debts,

\footnotetext{
${ }^{19}$ The system consisted in giving workers forced loans that they would have to repay with their labour and which thus served to retain them.
} 
which were very much at odds with the rules of a free market (Romano 2004). The naval industry also expanded in some zones to the extent that they dedicated a greater portion of their budgets to defence and introduced European techniques in shipbuilding (Goodman 1997). If during the period 1551-1600 the vessels built in America constituted just 2.7\% of those in the Old World, this proportion rose to $26.5 \%$ and then $22.06 \%$ during 1601-1650 and 1651 and 1700, respectively (Romano 2004, p. 261).

Mining, where the expansion of mercury-based systems of amalgamation provided a good example of the same march forward, also offers another dimension of this phenomenon: in spite of the well-established inefficiency of the Crown's chosen systems, growth in this sector would be a fact. The case of iron mining, vital for this growing economy, and of the use of potassium nitrate and sulphur, vital to the production of gunpowder, or salt, whose production was supposedly controlled by Crown monopoly systems, are very expressive (Romano 2004, pp. 145-8). If, perhaps, its development would have been still greater in another institutional context, still the production of these goods grew thanks to clandestine or semi-clandestine forms of production typical of an economy where informal networks and their capacity to generate confidence played a highly relevant role.

Contraband - an expression of the lack of efficiency of formal institutionswas, however, the cornerstone of a commercial growth that was pushing forward many of these sectors. These were illegal or semi-legal systems that by definition functioned on the basis that it was impossible to recur to the Crown as a guarantor of contracts and as a form of reducing risks and transaction costs. But at the same time, these were activities in which informal networks were able to generate forms of confidence through reputation, family, and extended family networks and formulas of a similar sort and so push forward an economic expansion.

All in all, the outcome of formal institutions that were in principle an obstacle for economic growth was not economic inactivity or recession. Rather the development of an informal sector of the economy that added to-and sometimes mixed with-activities more easily detectable by the authorities generated increasing quantities of wealth. ${ }^{20}$ As a result, the so-called 'crisis of the seventeenth century' appears to have been more a coming together or super-

\footnotetext{
${ }^{20}$ This is not to say that state action did not have effects upon the economy. To give just one example, everything indicates that the crisis of the New Spain's workshops or obrajes after 1630 should be understood in relation to not only the momentary crisis of the mining sector in the region but also to the Crown's prohibitions of commerce with Peru, as a means of protecting the export of these goods from the metropolis (Miño 1991, p. 108).
} 
imposition of alternate economic cycles which, since the middle of the sixteenth century, had brought about more or less constant growth. Of course, another matter was the type of society and political regime that generated this system, as well as its effect of exacerbating economic and social inequalities and intensifying the imperial exploitation of thousands of peoples.

\section{Regional Recession and New Growth Patterns IN IBERIA, C. 1600-1668}

As in other areas of seventeenth-century studies, the vision of the Iberian economy in this period has been very negative. Not only was it seen as being in crisis but also in recession and even in decline (Llopis 1994). From an international perspective, Spain and Italy served by their very nature as the stages for the crisis of the seventeenth century brought about to a large extent by the survival of feudal structures (Hobsbawm 1954).

A vision of this sort should, however, be set in the context of a wider literature that has revised downwards the capacity of the state to extract resources from society (Collins 1988) and poses the question of the real impact of formal institutions upon the economy. It is also interesting to study the so-called 'crisis of the seventeenth century' in relation to the general changes occurring in Europe's economy, whose relationship with the process of globalization was very close indeed. In this sense, and as Jan De Vries has shown (1984), Europe passed from an urban model based on the development of the cities of the interior to one which, progressively but decidedly, was to unfold in the coastal cities, which were more directly affected by international commerce. This process also combined with the shifting of urban dynamism towards the north of Europe and specifically into an area between Paris, Hamburg, and London. And this change was associated with the capacity of countries such as Holland, England, and, increasingly, France to build mercantilist political formations capable of capturing higher proportions of world commerce. See these trends in Maps 8.1, 8.2, 8.3, and 8.4.

The question, therefore, is: did the Iberian economies adjust to this scheme? And what were the transformations and factors that conditioned them?

\section{Big Trends, Big Numbers: Recession in the Empire's Core}

Recent studies on the Spanish economy of the epoch have shown that in the first half of the seventeenth century, a fall in real output per capita occurred that was even more intense and long-lasting than in other countries, Italy included (Álvarez Nogal and Prados de la Escosura 2013, 


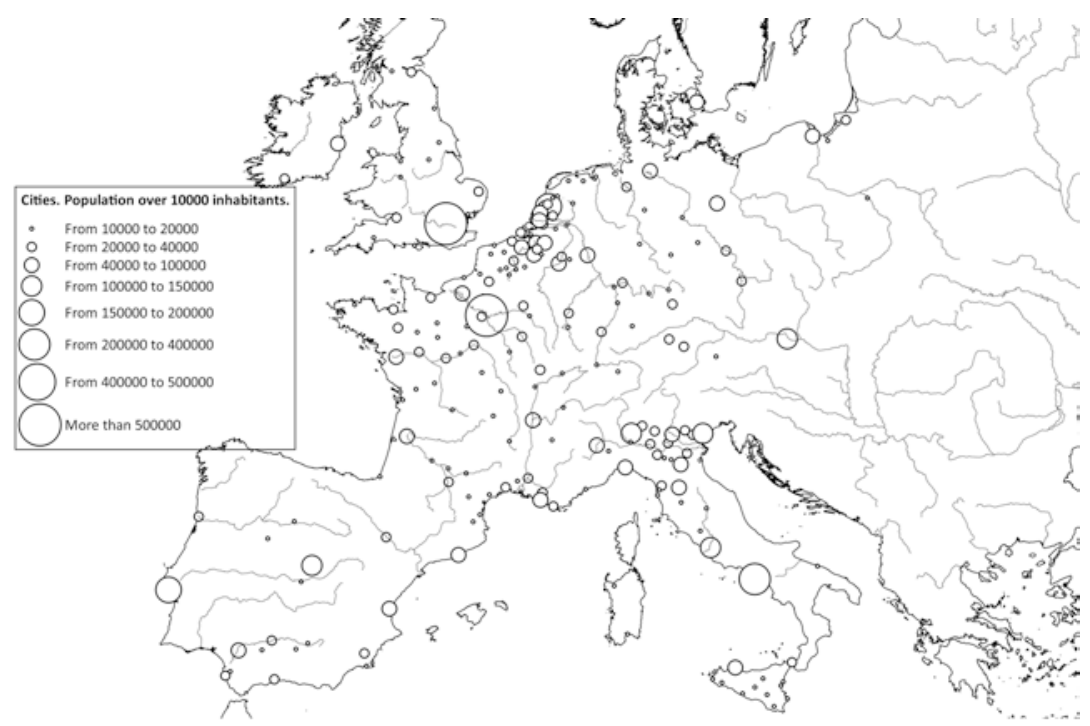

Map 8.1 European urban networks, 1700

Sources: My own elaboration with data from De Vries (1984) and my data of Spanish towns.

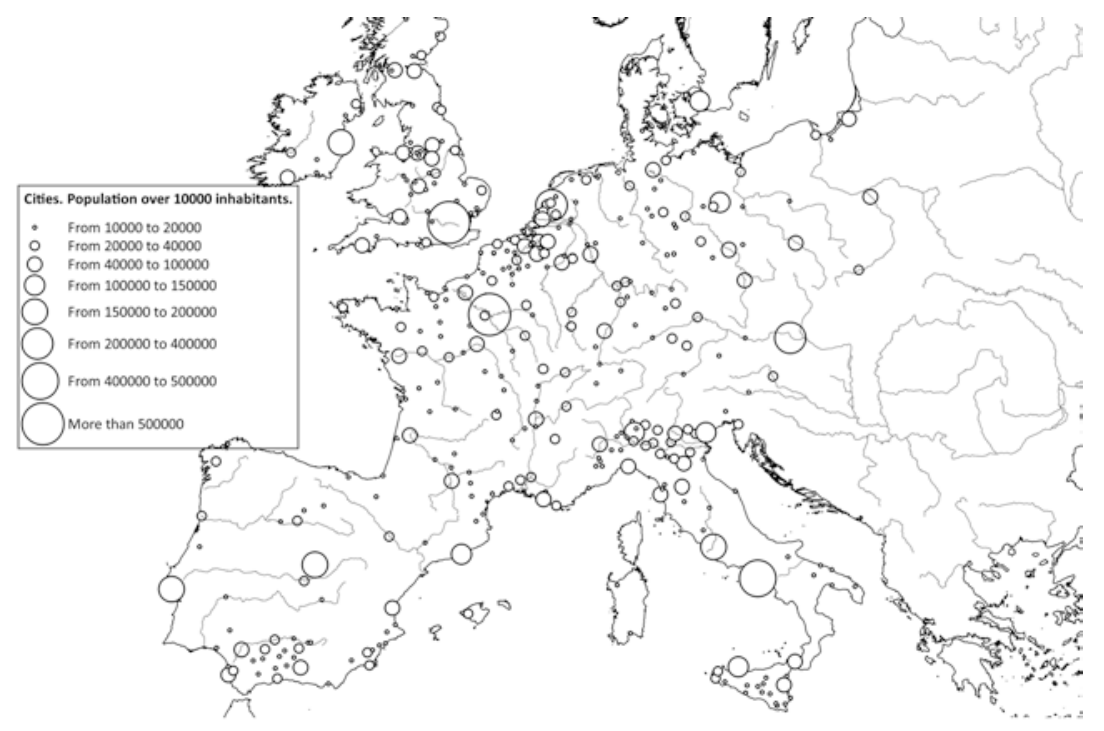

Map 8.2 European urban networks, 1800

Sources: My own elaboration with data from De Vries (1984) and my data of Spanish towns. 


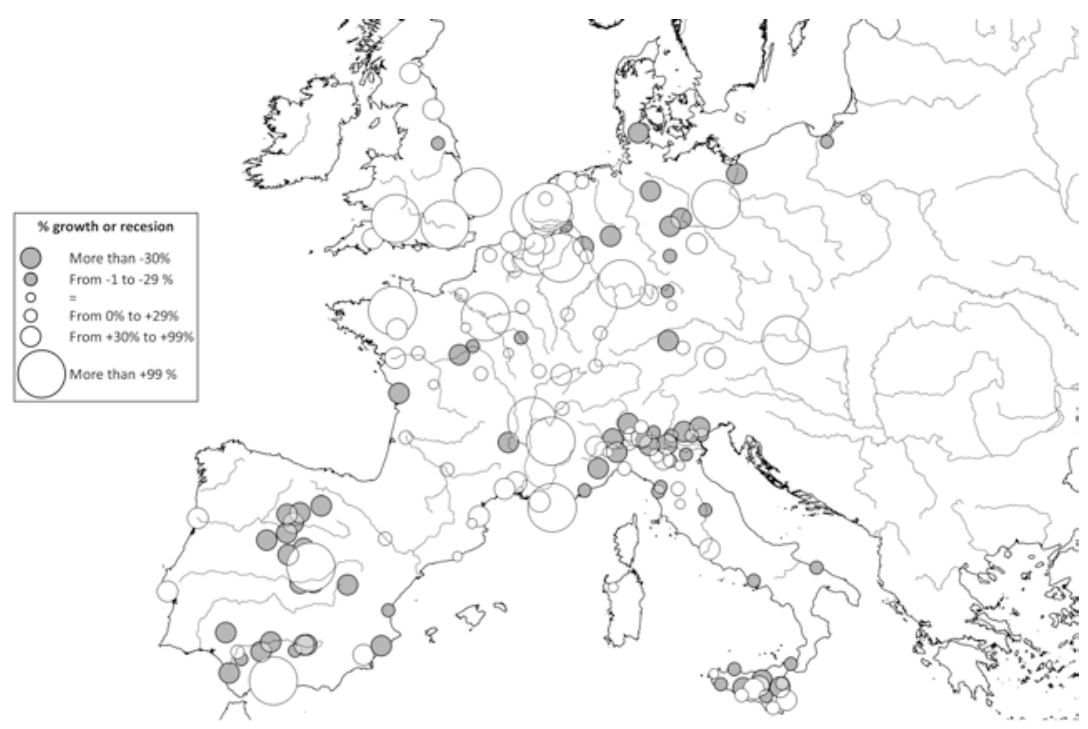

Map 8.3 Growth and recession of the European urban networks, 1600-1700 Sources: My own elaboration with data from De Vries (1984) and my data of Spanish towns.

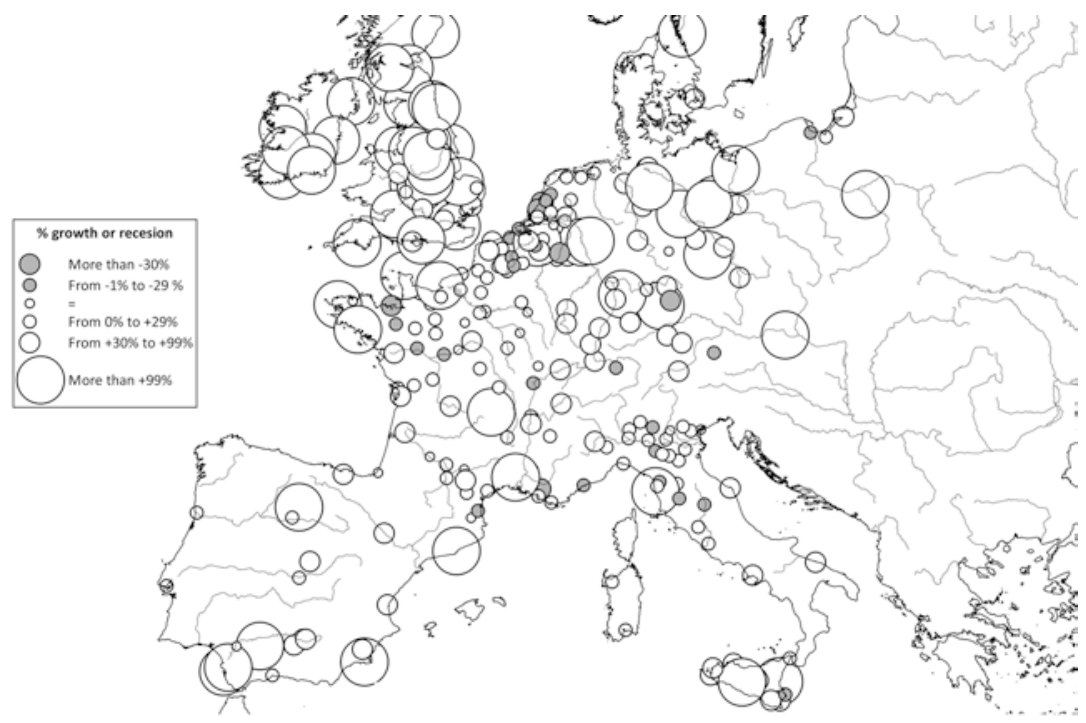

Map 8.4 Growth and recession of the European urban networks, 1700-1800 Sources: My own elaboration with data from De Vries (1984) and my data of Spanish towns. 


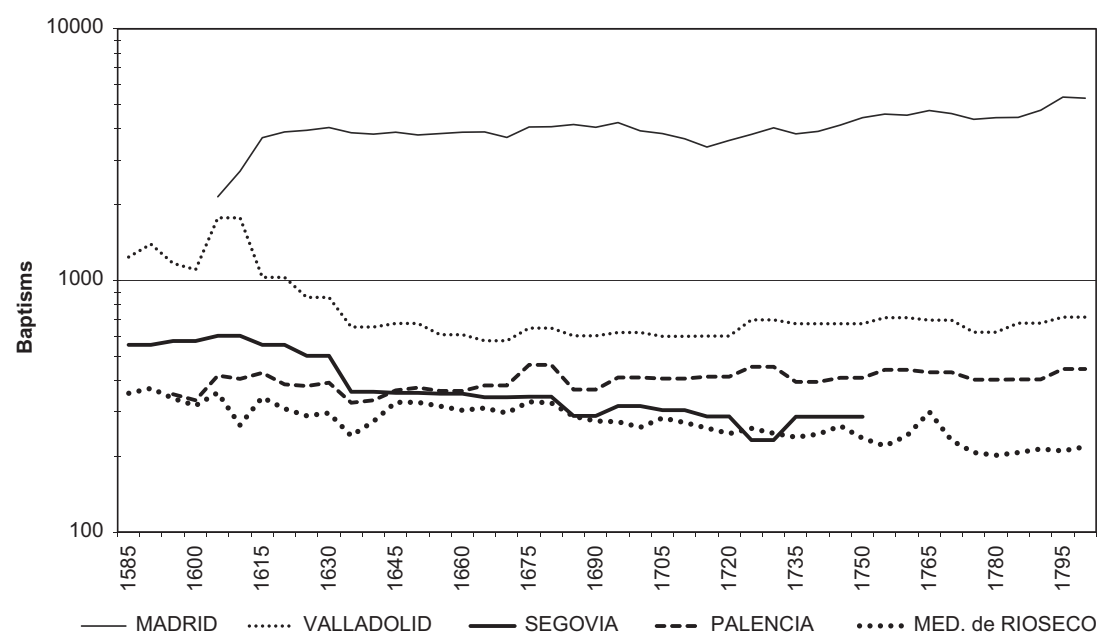

Graph 8.1 The demographic crisis—and recession—of the cities of the Duero Valley and the expansion of Madrid Sources: Yun (2002b).

figure 7 , table 1). This situation appears evident in the centre of the Iberian Peninsula, and above all on the Castilian plateau, where the end of the sixteenth-century crisis gave way to an economic recession accompanied by structural changes. ${ }^{21}$

The dismantling of the previous urban network continued, while Madrid's macrocephaly was reaching its zenith (Gelabert 1995. See Graph 8.1 in this chapter). The organization of an empire in which rent-seeking management and royal favour were good choices for palliating the rigidity in seigniorial incomes further accelerated the migration of noble and patrician families towards Madrid, where royal patronage was dispensed, information costs on the marriage market were lower, and informal lineage networks were more efficient. With the shifting of conspicuous consumption to the court, the service and construction sectors, the two most highly affected by elite spending patterns, entered into recession in the cities of the Duero Valley. ${ }^{22}$

\footnotetext{
${ }^{21}$ The reader can find some of the following arguments with more visible empirical evidence in Yun (1999c, 2002a).

${ }^{22}$ Cases such as that of Valladolid are highly expressive (Urrea 1996). Madrid, in contrast, underwent the very opposite process (Ringrose 1983a, pp. 112-4). On the migration of artisans to Madrid, see Nieto and Zofío (2016).
} 
Without being the only cause of the problems (Chap. 6), fiscal pressure did not help industry while monetary manipulations negatively affected trade in one of the peninsula's more monetized areas. The peace settlements of the early 1600s facilitated the country's inundation by northern light fabrics, thus aggravating the difficulties of Castilian industries, which were unable in the short run to challenge the imports by imitating northern techniques. Yet this was not simply the result of political developments: it was, in many regards, a consequence of the function of international commercial networks. The growing need for silver and other colonial products for Dutch commerce in the Baltic intensified even further their interest in capturing these goods in Spain and America and, by this route, attempting to level out the commercial balance with Castile (Israel 1990, pp. 44-5, and 54). Despite the occasional blip, English commerce in the Mediterranean continued to expand, and increasing quantities of raw materials for industry, such as silk, travelled to the North, while ever greater amounts of British 'new draperies' were sold in the Mediterranean areas (Brenner 1993, table 1.3). Spain became the 'leading market outside northern Europe for English cloths', and by 1620 Albion's merchants were selling products at below their production price purely as a means of gaining access to goods from America (Brenner 1993, p. 30). It was no coincidence or accident that several regional industrial centres should have collapsed at this juncture or that the silk industry of Toledo was also running into difficulties. Granada had already entered into crisis and was now more focused on the export of raw silk. Furthermore, foreign competition in silk fabrics and other Asian products in the American market became more intensive. ${ }^{23}$

Madrid represented exactly the sort of marketplace that was relatively easy for foreign products to penetrate. Being a highly concentrated market, it involved relatively low transport and distribution and retailing costs, once foreign products had passed through its city gates; these were, precisely, the conditions most favourable to foreign goods, given the high proportion of their final price that derived from expenses incurred in their shipping and delivery. Research into the five great guilds of Madrid (the Cinco Gremios Mayores de Madrid) in later periods demonstrates the complex framework of competing interests that facilitated the distribution of imported goods (Pérez Sarrión 2016). Once Madrid had been taken, a very high percentage of the Castilian market had been won. The other important market,

${ }^{23}$ Gasch (2012), Boyajian (1993). 
America (in other words, Seville), had similar characteristics (above all else, a high degree of spatial concentration) and operated according to rules that were highly favourable to foreign production (Chap. 7).

The restructuration of the interior urban network was accompanied by important changes in the rural sector. The demographic trends both in towns and the countryside of this area are of evident recession (Yun 2004). The trends discernible in the tithes show similar tendencies, and wheat production declined by some 30\% between 1600 and 1630 (Yun 1999a, table p. 54). In previous centuries the slow movement of inhabitants towards the south had brought overall benefits (Chap. 3). This was no longer the case, as emigrants no longer relocated in order to farm highquality soils; nor was this process as positive for the redistribution of land and labour as it was in the sixteenth century. On the contrary many displaced families flocked to Madrid, whose growth continued unabated until 1630-1640 due to the arrival of artisans but also of marginalized people. The new model of the urban network in the interior, with Madrid disproportionately large and influential, and a very weak urban network around, made this commercialization more difficult. It was also accompanied by a system of forced purchases exercised by Madrid (Ringrose 1983a) that, being focused on the large proprietors, redistributed the commercial benefits among a very small elite of the peasantry.

Similar trends occurred in Extremadura and the interior Andalusia, as well as, quite possibly, in the Alentejo, in part because of the relative drying up of the flow of emigrants from the North. There are reasons for suspecting that the level of resistance to collapse may have been greater in these regions. But an agrarian system based on large properties, many of them devoted to less demanding labour crops - or only requiring seasonal work, such as harvesting olives trees-or to livestock farming, retarded demographic recovery and at best provoked stagnation. In the interior of Spain, only New Castile retained any resistance to decline. To be specific, baptisms recorded in the rural areas of this region fell more slowly than those of the Duero Valley (at least this was the case until 1640), as did the tithes (until 1630).

\section{Crisis and Adaptation in the Peninsula's Periphery}

As we have seen, if the problems in the periphery should not be overlooked, then the depth of the crisis and recession in the Iberian interior has led to extrapolations on the overall peninsula position that are not at 
all correct. Above all, the calculations of Prados de la Escosura and Alvarez Nogal have to be nuanced. In a pioneering and seminal study, these scholars base their estimate of GDP on the evolution of the cities. This approach predominantly reflects the decline of the central areas where the biggest cities were concentrated and which was the largest of the country. Therefore, if in terms of 'Spain' the figures can be correct, these estimates do not represent the regional differences, which are crucial in an economy composed in fact by the aggregation of regional subnational circuits. The resulting figures fail to include a more precise vision of developments in the peripheral zones, where small population centres and reasonably active rural economies were very dominant. In fact, the crisis did not have the same chronology and outcomes in other regions of the peninsula, and whether or not the crisis led to a recession depended on many factors, ecological conditions among them.

The problems were very obvious in the region from Galicia to Navarre, roughly the so-called Atlantic Spain (Chap. 3). Here, again, there is the sense of a world that was full to the brink and was being punished for its demographic hubris with outbreaks of disease. The 'boom' of the Armada years was followed by a deep 'bust', in which naval construction ran into serious difficulties (Goodman 1997). The severing of trading links with the north of Europe, the outbreak of wars with Flanders and England, and the growing privateering threat in the Atlantic posed a range of problems (Fernández de Pinedo 1974, p. 31). These did not, however, end the Basque iron industry, although it was comparatively resistant to change and technical innovation and clearly affected by the contraction of internal demand. For these reasons the sector was unable to replace lost imports and reduce costs, thus forfeiting its competitive edge in relation to its overseas rivals (Bilbao 1987, pp. 52-7). And all of these setbacks came on top of the contraction of the trade that linked some of these areas to other regional economies in the interior of the peninsula (Lanza 1991, pp. 121-2; Yun 1987). Around 1600, then, many of the sectors that had facilitated the expansion of the previous century were in trouble. Contact with outside regions was limited, as is demonstrated by the fall in commerce with the Duero Valley from 1610 to 1620 (Yun 1987) meaning that it was increasingly difficult to gain access to specie. The scarcity of cash had always been crucial to economies of this sort, which needed it to overcome deficits in basic products. Though many nuances should be added, one could accept the proposition that the region went through a crisis between 1590 and 1615-1620. 
Yet, the overall pattern would be very different from that of Castile. The region's ecological conditions meant that it was always able to turn slowly to new alimentary resources such as rye, the chestnut tree, and millet crops or those provided by the fishing industry or domestic livestock breeding. The abundance of forests guarantied the existence of a valuable cattle livestock and of a wide spectrum of food resources (Anes 1994). This ecosystem was receptive to the slow but continuous diffusion of maize from the beginning of the century, which greatly favoured its resistance to the food crisis. ${ }^{24}$ And the fiscal burden took different forms here. The tax model based on sisas levied on commercial products would have a lesser impact in a region where family self-consumption was more common. Indeed even the products upon which taxes fell appear to have been less decisive - this was the case with wine, for example - and the final result was to avoid a recession of great intensity and scale (Saavedra 1993). The Crown had never sold lots of common lands in this region. The mid-term impact of the wars in Northern Europe was less than has been thought, and naval construction recovered sooner than has been thought (Grafe 2006; Valdez-Bubnov 2011, pp. 73-88). These features help to explain why, for all the problems of the early seventeenth century, in Galicia, Asturias, Cantabria, the Basque Country, and Navarre, the fall in the number of baptisms came later and was slower than in other regions of Spain to the extent that the impression is more that of a crisis with stagnation rather than recession (Yun 1999a; Lanza 2010).

A picture of similar balances and nuances emerges from the great arc that runs from the Catalan Pyrenees through the Levant coasts to Eastern Andalusia. The problems affecting this large strip of land were in part similar to those of Castile: the consolidation of the seigniorial system, the relative depreciation of landlords' incomes and the consequent struggle for produce, and the increasing indebtedness of the aristocracy and the rise of a peasant elite were also present here. As in the hinterland, landlord debts and pressure upon vassals were also factors (Casey 1983, pp. 135-6). In Valencia, for example, the uneven balance of pasture and arable lands posed considerable difficulties and was exacerbated by the crisis in transhumance livestock breeding (Casey 1983, p. 53). These problems were even clearer in Murcia. The expulsion of the Moriscos from 1609 also deprived these two areas of very valuable human capital with great skill in

\footnotetext{
${ }^{24}$ See Saavedra (1985), Barreiro (1984 pp. 296-303), Anes (1988 pp. 34-5), Fernández de Pinedo (1974), and Lanza (1991 pp. 158-77).
} 
irrigation, intensive agriculture, interregional trade, and silk production (Casey 1983; Vassberg 1996). The urban economy, industry, and trade were also sailing into choppy seas. Partly this was because the money market did not favour the free flow of capital towards productive activities, as can be understood from the complaints about the censals levied on landlord incomes in Valencia (Casey 1983, pp. 95-7). The growth of the borrowing by municipalities and the Generalitat in Catalonia must have had a similar effect. The silk industry of Valencia was being squeezed out by more competitive rivals. As in Castile, silk was slowly being transformed from a primary material used in domestic industry into a raw material exported to other areas of Europe (Casey 1983, pp. 89-92).

There were, however, some differences with Castile, which affected both rural and urban dynamisms. The spiralling number of estates and mayorazgos was not present to the same extent as in Castile. Moreover, in this broad eastern arc (and in Catalonia especially), the lower participation of the nobility in the imperial endeavours limited the importance of rent-seeking strategies and the search for political rents in the court as a substitutive for better economic management. ${ }^{25}$ This led, as we have seen, to banditry and insecurity in the countryside, which might have meant high transaction costs, but also improvements when the problem almost disappeared during the second half of the century. The agricultural sector was, moreover, notable for a certain dynamism in some areas. In Catalonia changes were occurring that saw the diversification of crops linked to the masia and a more intensive agriculture in relation to the interior of the peninsula. ${ }^{26}$ Until 1620-1625 the French emigration into Catalonia and, to a lesser degree, Valencia continued, and Murcia was able to repopulate uninhabited areas in these decades. ${ }^{27}$ Not even a blow such as the sale of the tierras baldias $y$ concejiles had the effect that it might have done in areas of Castile.

Eva Serra's study (1988) also reveals a growing diversification of production which was part of an agriculture aimed at producing goods for the market and based upon wine, rice, the mulberry tree, and citric fruits (Vilar 1962, vol. I, pp. 389-90). These efforts not only allowed it to commercialize a greater percentage of its final produce but also to defraud

\footnotetext{
${ }^{25}$ Of course, this consideration did not include the juros in relation to Catalonia (Vilar 1962, vol. I, pp. 357-62).

${ }^{26}$ Vilar (1962, vol. I, p. 371), Durán (1998, p. 133), Serra (1988, pp. 404-5).

${ }^{27}$ On Catalonia see Nadal and Giralt (1960, p. 69) and Durán (1998, pp. 128-31). On Valencia, Casey (1983, pp. 6-7).
} 
a higher proportion of rent due to landlords, thus reducing the pressure upon the peasantry. In both Valencia and Murcia, the expulsion of the Moriscos meant a lost opportunity for agrarian improvements but eventually resulted in the redistribution of economic activity and population, allowing for the emergence of a cereal-based agriculture in the dry lands. This switch entailed major changes. In Valencia the population was increasingly concentrated in littoral zones near the capital, a transformation which, it seems reasonable to assume, led to closer links between the countryside and city. As in Catalonia, hopes were founded on new commercial crops. This was the case for rice, the vine, maize, and barilla, a plant linked to the booming glass industry and the production of soap. These advances were matched by drives to expand the irrigation system and even efforts dating back to the previous century to break new grounds (Casey 1983, pp. 51-8; Pérez and Lemeunier 1984, pp. 115-119). The development of the market can be discerned behind all of these initiatives; other significant factors were the reorganization of property, leading to the concentration of lands in medium-sized farms which represented a greater balance between the available lands and the workforce (Furió 1995, pp. 324-6). Landlords of the sort found in Valencia, who drew their incomes from partición de frutos (the sharing of rent in kind) or farms leased over the long term in enfiteusis, could only encourage improvements in production: in this regard their interests coincided with those of their peasants or vassals. Property rights were positive here for economic recovery (Furió 1995, pp. 329-31). Combined with a greater flexibility in the land market and the lower impact of entitled lands, the overall result was a slow but clear recovery (Peris 1989, p. 501).

Cities too were in crisis but also far from collapsing. The arrival of new spices from Asia through Mediterranean trade (Chap. 7) would have a positive effect upon ports such as Alicante, which became a point of distribution towards the peninsula's hinterland. Alicante would also become a conduit into the Mediterranean for goods coming from America (Casey 1983, pp. 82-4). Until at least 1620, the benefits of American trade and the northern commercial networks were felt from Malaga to Almeria (Pulido 1993). Other sectors of the economy remained active. Even at the end of the sixteenth century, the silk trade continued to be relatively stable, with links stretching from Valencia and Murcia to Toledo. In Catalonia and Valencia, the fiscal burden had not grown here as much as in the Meseta, and the type of taxes was not as negative as the millones. Furthermore, the coastal regions of eastern Spain had suffered on account of the censales. But 
the more moderate character of institutional debts - if we compare with the Castilian state's juros and the municipal censos-meant that the deviation of capital from more productive investments like commerce was less intense (Vilar 1962, vol. I, p. 360). With bonds now providing lower yields and levels of seigniorial indebtedness having reached their natural limit, a more logical choice for investors was henceforth to plough their monies into commerce and productive activities. This conclusion was not entirely unexpected, for, as we have seen, in countries such as England, a similar process had occurred, albeit to a greater degree. The most important case was the textile sector of Barcelona. Here the problems of the guild-based industry would give rise the verlagssystem, more efficient and flexible at balancing offer and demand (Vilar 1962, I, pp. 383-387). Being situated on the coast, the eastern cities had the considerable advantage of a secure and regular provisioning system.

These positive forces also had an impact on the Mediterranean coasts of Eastern Andalusia. Although the crisis of the Granada silk industry was apparent, it did not disappear (Garzón 1972). More important, the coastal areas began benefiting from the slow but clear recovery of Mediterranean trade. The arrival of the Dutch and, above all, English animated small ports of the area and cities such as Malaga. Another part of this trade consisted of products arriving in Seville and connected with the rest of the Mediterranean. One effect was the beginning of the cultivation and trade of raisins, which would subsequently become the most dynamic sector from the end of the century.

In many respects Portugal and, specifically, its littoral zones were similar to the description of the coastal areas of the Mediterranean and Cantabria. The available measurements on GDP per capita, as well as those of agrarian production, show that growth slowed from 1570 but that, after a levelling-off until 1625, they experienced a slow but sustained expansion until 1700. This phenomenon should be tied to American commerce and left its mark in the expansion of cities such as Lisbon and, above all, Porto. The second half of the seventeenth century witnessed an agrarian expansion similar to that of the Spanish littoral: based on enfiteusis, it began with the development of commercial crops-wine would be the best example and the Porto zone the most important-and even exports (Barros 2007). Ties with England, more solid after the Restauraçao, were behind this expansive process and gained strength thanks to English interest in exports to Brazil. It has been convincingly demonstrated that due to 
this development, the empire's contribution to seventeenth-century Portuguese growth was very positive (Costa, Palma and Reis 2015).

Thus, the so-called seventeenth-century crisis came later in some of these regions and was smoother and shorter than in the centre of the peninsula.

\section{A New Pattern of Growth}

It is impossible to deny the drama of the problems of the first decades of the century, above all if one considers that it was accompanied by the enormous loss of lives and poverty and that the economy was unable to comply with its fundamental mission in ancien régime societies: to maintain population levels.

But this is only evident in some regions, and the crisis also set down the grounds for a new expansive model, which was characterized by the major dynamism of the Iberian periphery (Ringrose 1996). Though intensities varied, the economic recovery was also felt in the centre during the second half of the century. This is not the place to attempt an explanation of this revival. ${ }^{28}$ As always in pre-industrial economies, it was due to readjustments of a Malthusian type, a better balance between livestock and crops, and the lowering of land rents (Anes 1994). The crisis also had positive effects as long as it provoked a redistribution of income. Variables such as the land rent-wage ratio, measuring the imbalance between landowners and workers, fell between 1590 and 1650 (Álvarez Nogal and Prados de la Escosura 2013, p. 9). These readjustments were also due to changes in the distribution of property. The concentration of land property and the emergence of new seigniorial estates in which land incomes rather than seigniorial rents were the basis of revenues activated the need to lease out lands thus creating better conditions for peasants able to rent those properties and for agrarian recovery. The concentration of capital in the hands of ecclesiastical institutions meant that they were increasingly able to offer censos and loans to farmers at interest rates below official levels. Beyond this, an even more complex bundle of factors was also at play. In any case, this explanation appears clear from this date when the evolution of baptisms is examined (Graph 8.2). And the same can be said of the development of tithes and even of the indicators of interior commerce (Yun 1999a).

\footnotetext{
${ }^{28}$ The reader interested in my own view can see it in Yun (1999a).
} 


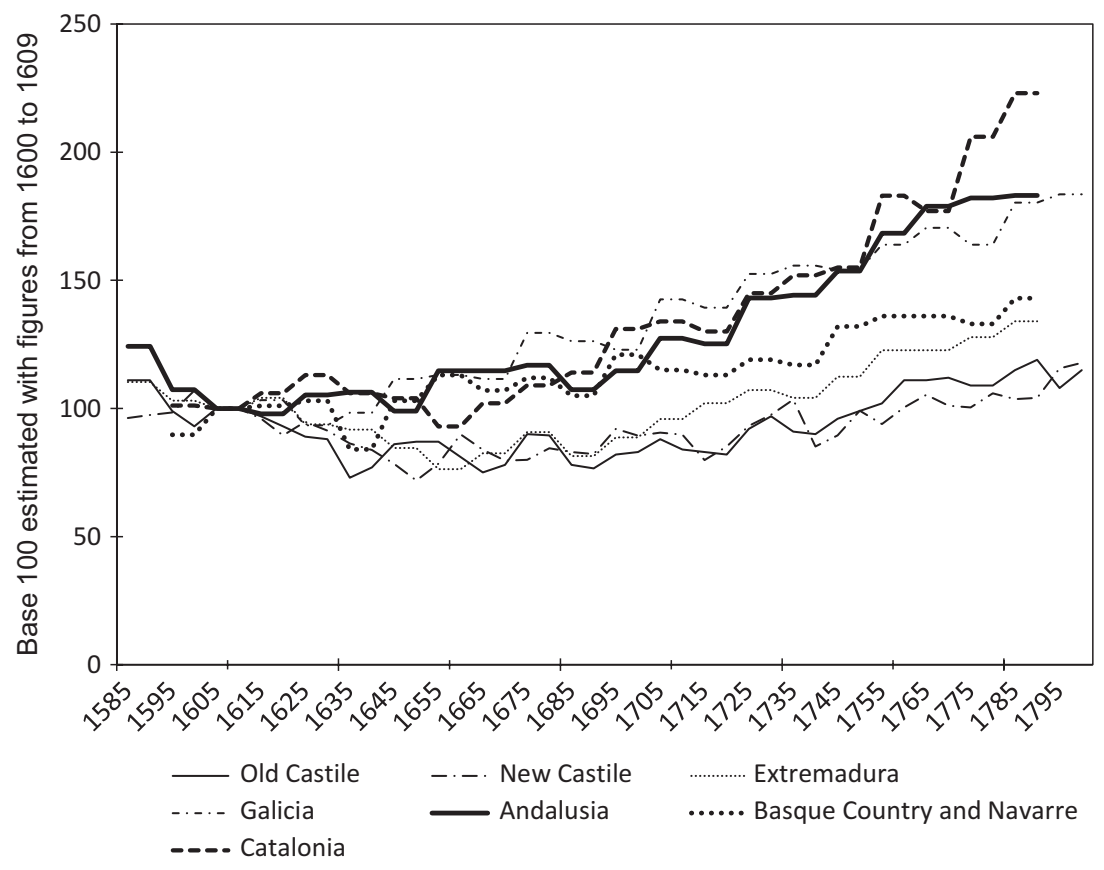

Graph 8.2 Interior and periphery in Spain: baptisms in rural areas, 1585-1800 Sources: Yun (1999b).

It is very possible that, looked at as a whole, the evolution of the Spanish economy of the period may have been very similar to the Italian one, as described by Federico and Malanima (2004). The existing studies on Portugal also point in this direction (Palma and Reis 2016). In the final analysis, Portugal was simply another peripheral region of the Iberian Peninsula. This having been said, the subalpine crisis was shorter and perhaps more creative than its Iberian counterpart (or, at least, that of Spain). But what happened in Spain was not different from the developmental model that was emerging in Europe, although perhaps its intensity or rhythm was. Maps on the density of town and city habitation demonstrate that Spain - though more slowly-did recover its sixteenth-century levels of urbanization (Álvarez Nogal and Prados de la Escosura 2013, table 2). As in the European model described by De Vries, 
peripheral cities such as Lisbon, Porto, Barcelona, Cadiz, Malaga, and Valencia replaced the dynamism of the centres of the interior such as Segovia, Salamanca, Toledo, or Valladolid. See Maps 8.1, 8.2, 8.3, and 8.4, which show patterns similar to the rest of Mediterranean Europe with urban recession between 1600 and 1700 and the slow but clear growth of coastal cities, with the exception of the Cantabrian coast.

In the second place, this recovery was achieved without a radical overhaul of the basic institutional framework, even if small rectifications had been made to it. This is all the more interesting to the extent that, as we have seen (Chap. 5), this framework was not in itself very positive for economic development. As in the American case, but at a much more modest level, the relative abundance of resources, ecological conditions, small changes in property rights, leasing systems (such as the spread of enfitensis and long-term leasing), and international commerce could create conditions in which recovery and growth were possible. Also, the fact that the pacts among elites, and the institutional framework derived from them, were very different in each region, which was logical in a composite monarchy, reduced the chances of the obstructions presented by the institutional framework prevalent in Castile from affecting the peninsula as a whole in the same way. As a result, the recovery of specific regions was perfectly possible. And, with all its limitations, these were capable of generating stimuli to the extent that they consolidated a national economy. But this matter really belongs to the history of the eighteenth century (Ringrose 1996).

Around 1668, when the Treaty of Lisbon established peace between the Habsburg and the Braganza, the peninsular model of economic growth was already designed in a manner very similar to that of the rest of Europe.

This situation coincided, moreover, with a critical point at which both dynasties saw their own and their metropolitan territories' capacity to benefit from the possession of empires as very limited. The networks of international commerce operated in a way little favourable to such benefits (Everaert 1973) and globalization in Asia, Africa, and America were behind this circumstance. The institutions created in these processes were inefficient for such purposes, not by nature but, rather, because they were becoming obsolete. The paradox was evident: in a world like that of the eighteenth century in which growth would centre on the coasts and on ties with international commerce, two of the countries most oriented towards global circuits would grow slowly. Yet this is not the place to explain this situation. In any case, it is worthwhile to recall that Spain as well as Portugal witnessed important attempts at reform as early as the final decades of the seventeenth century, which demonstrate a certain 
capacity for adaptation (Storrs 2006). Many changes were still taking place. The increase in the number of noble titles was generating a new aristocracy, coastal areas grew to the rhythm of international exchanges, and cities like Barcelona or Cadiz benefited from the process and nurtured promising mercantile groups. Nevertheless, international competition would be fierce and the changes perhaps slower than desired. A new stage began in the history of empires and, therefore, of globalization.

Were these, then, decadent empires? From the moral perspective set out from a Whig view of history-in other words, the perspective of the Black Legend too-this was obviously the case. Corruption, as so many Enlightenment writers including Spanish and Portuguese thinkers claimed, was the order of the day in Iberian countries and their colonies. The same is true if we limit ourselves to the outcomes of international treaties, such as Munster (1648), Westphalia (1648), the Pyrenees (1659), and Lisbon (1668). Madrid was losing influence, and the European dominions of the Habsburgs were retreating, at the same time as the interference of other countries in the colonial monopoly was being legalized. Lisbon was starting to create a new state whose backbone, not by chance, would be a tax state with high implication of the kingdom but whose empire would very much depend upon English support.

On the other hand, neither today's moral perspective nor the first steps towards the disintegration of the imperial project provide the only viewpoints from which to assess the reality of the so-called Spanish and Portuguese empires and the composite monarchy that served as their bases. What the Enlightenment interpreted as corruption was part of a political system and a conflictive pact that afforded the empire its longevity. It flowed through its very heart, as a part of the need for the consolidation and circulation of elites. And this came at the same time as the American economy maintained a high capacity for recovery and the Spanish and Portuguese economy was passing through a long crisis but one that was not in any way exceptional in qualitative terms in the Mediterranean context and from which it would eventually recover, despite everything. On the other hand, a basis had been established in Spain that, once the separation from Portugal had been overcome, allowed the pact between the distinct centres of imperial power-and, above all, 
those between Madrid and the colonies - to survive for many years. That was also the case of Portugal with the very few remaining centres in Asia and Africa and, more important, with Brazil. The principal objective-and perhaps another way to assess the empires' success-was achieved: their own survival. No further essential disintegration would occur until the advent of the final crisis from 1808, nor would any major state succeed from it. The problem, as the epilogue will show, is that many things had changed in the international political landscape in or around 1668. And also a very important change had taken place in Iberia: the construction of absolutist systems in which negotiations between the Crown and the elites were based less and less on corporative bodies, such as the Cortes, and more and more on a tension, increasingly unequal, between the king, on the one side, and a myriad of social actors who often maintained different and clashing interests. This situation was not necessarily negative for some of these social actors but would make it more difficult to create wealth for the whole society. 
Open Access This chapter is licensed under the terms of the Creative Commons Attribution 4.0 International License (http://creativecommons.org/licenses/ by $/ 4.0 /$ ), which permits use, sharing, adaptation, distribution and reproduction in any medium or format, as long as you give appropriate credit to the original author(s) and the source, provide a link to the Creative Commons licence and indicate if changes were made.

The images or other third party material in this chapter are included in the chapter's Creative Commons licence, unless indicated otherwise in a credit line to the material. If material is not included in the chapter's Creative Commons licence and your intended use is not permitted by statutory regulation or exceeds the permitted use, you will need to obtain permission directly from the copyright holder.

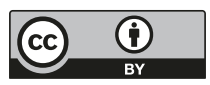

